\title{
Protoliths and phase petrology of whiteschists
}

\author{
Leander Franz $\cdot$ Rolf L. Romer $\cdot$ Christian de Capitani
}

Received: 4 September 2012/ Accepted: 8 March 2013/Published online: 26 March 2013

(C) Springer-Verlag Berlin Heidelberg 2013

\begin{abstract}
Whiteschists appear in numerous high- and ultrahigh-pressure rock suites and are characterized by the mineral assemblage kyanite + talc (+-quartz or coesite). We demonstrate that whiteschist mineral assemblages are well stable up to pressures of more than $4 \mathrm{GPa}$ but may already form at pressures of $0.5 \mathrm{GPa}$. The formation of whiteschists largely depends on the composition of the protolith, which requires elevated contents of $\mathrm{Al}$ and $\mathrm{Mg}$ as well as low $\mathrm{Fe}, \mathrm{Ca}$, and $\mathrm{Na}$ contents, as otherwise chloritoid, amphibole, feldspar, or omphacite are formed instead of kyanite or talc. Furthermore, the stability field of the whiteschist mineral assemblage strongly depends on $\mathrm{XCO}_{2}$ and $\mathrm{fO}_{2}$ : already at low values of $\mathrm{XCO}_{2}, \mathrm{CO}_{2}$ binds $\mathrm{Mg}$ to carbonates strongly reducing the whiteschist stability field, whereas high $\mathrm{fO}_{2}$ enlarges the stability field and stabilizes yoderite. Thus, the scarcity of whiteschist is not necessarily due to unusual $\mathrm{P}-\mathrm{T}$ conditions, but to the restricted range of suitable protolith compositions and the spatial distribution of these protoliths: (1) continental sedimentary rocks and (2) hydrothermally and metasomatically altered felsic to mafic rocks. The continental sedimentary rocks that may produce whiteschist mineral assemblages typically have
\end{abstract}

Communicated by T. L. Grove.

Electronic supplementary material The online version of this article (doi:10.1007/s00410-013-0874-5) contains supplementary material, which is available to authorized users.

L. Franz $(\bowtie) \cdot$ C. de Capitani

Mineralogisch-Petrographisches Institut, Universität Basel,

Bernoullistraße 30, 4056 Basel, Switzerland

e-mail: leander.franz@unibas.ch

R. L. Romer

GFZ German Research Centre for Geosciences,

Telegrafenberg, 14473 Potsdam, Germany been deposited under arid climatic conditions in closed evaporitic basins and may be restricted to relatively low latitudes. These rocks often contain large amounts of the clay minerals palygorskite and sepiolite. Marine sediments generally do not yield whiteschist mineral assemblages as marine shales commonly have too high iron contents. Sabkha deposits may have too high $\mathrm{CO}_{2}$ contents. Protoliths of appropriate geochemical composition occur in and on continental crust. Therefore, whiteschist assemblages typically are only found in settings of continental collision or where continental fragments were involved in subduction. Our calculations demonstrate that whiteschists can form by closed-system metamorphism, which implies that the chemical and isotopic composition of these rocks provide constraints on the development of the protoliths.

Keywords Whiteschists - Thermodynamic modeling . Metasomatism - Hydrothermal alteration - Palygorskite . Sepiolite $\cdot$ Geochemical constraints · Continental collision

\section{Introduction}

The term whiteschist was first defined by Schreyer (1973) for a crystalline schist with the characteristic mineral assemblage kyanite + talc, which had undergone highpressure metamorphism (i.e., pressures $>1 \mathrm{GPa}$ ). These rocks are typically rich in $\mathrm{Mg}$ and $\mathrm{Al}$, but poor in $\mathrm{Ca}, \mathrm{Fe}^{2+}$, and alkali elements (Schreyer 1974). Some investigators (cf. Sharp et al. 1993) expanded the definition of whiteschist including coesite-pyrope quartzites, which they regard as ultrahigh-pressure protoliths of high-pressure whiteschists. Whiteschists have been found in numerous high- and ultrahigh-pressure metamorphic areas (see Table S1 of the electronic supplement). A wide variety of $\mathrm{Al}-$ and $\mathrm{Mg}$-rich 
protoliths have been suggested for kyanite-talc-bearing rocks, including metapelites, acid volcanics, evaporites, quartz veins, or gabbroic rocks. Many of the models for the formation of whiteschists postulate a high degree of metasomatism during prograde metamorphism of whiteschists.

From experimental investigations in the MASH, MFASH, and KMASH system (e.g., Schreyer 1988; Wyllie 1992), it becomes evident that rocks with the mineral assemblage talc + kyanite characteristically form at elevated pressures of $>0.6 \mathrm{GPa}$ and temperatures of 600-850 ${ }^{\circ} \mathrm{C}$ and are limited to $\mathrm{Al}-$ and $\mathrm{Mg}$-rich lithologies with minor amounts of $\mathrm{Ca}, \mathrm{Fe}$, and alkali elements. Such compositional constraints are only very rarely met by the primary composition of rocks. Therefore, Schreyer (1974) rejected the idea that a single mechanism could be responsible for the development of such an unusual chemical composition. Experimental investigations of Hermann (2003; see also Hermann and Green 2001) showed that whiteschist assemblages may also form in the KCMASH system if there is no or very little ferrous iron present. Strong element mobility during weathering and metasomatic alteration has been postulated to be essential for the formation of numerous whiteschist occurrences. Protoliths, peak metamorphic P-T conditions, and references of whiteschist occurrences are listed in Table S1. These studies indicate that a wide range of different protolith lithologies with compositions, ranging from acid to mafic/ultramafic, may yield whiteschist mineral assemblages. For most whiteschists, however, a distinct element mobilization in the nonmetamorphic host rock or during metamorphism is postulated. Metamorphic peak $\mathrm{P}-\mathrm{T}$ conditions for the whiteschists are rather variable and range from elevated pressures to high- and ultrahigh-pressure regimes at intermediate to high temperatures (i.e., $500-890{ }^{\circ} \mathrm{C}$ at 0.6-4.4 GPa; see Table S1). In this paper, we focus on potential protoliths that are not whiteschists but would yield whiteschist assemblages if exposed to higher $\mathrm{P}-\mathrm{T}$ conditions. Our modeling demonstrates that a wide range of different protoliths potentially develops whiteschist mineral assemblages at high- and ultrahigh-pressure metamorphic conditions. We show that the production of whiteschists is not limited to metasomatically altered protoliths but may also include sedimentary rocks from continental and shallow marine environments. Furthermore, we demonstrate that whiteschist may occur in a wide stability field, which strongly depends on the chemical composition of the protolith and the availability and composition of metamorphic fluids.

\section{Phase petrology}

We reviewed numerous articles with chemical analyses of appropriate rock composition for whiteschist protoliths.
Hundreds of equilibrium assemblage calculations of metasomatic sedimentary, magmatic, and metamorphic rocks as well as unaltered sedimentary rocks were performed with the DOMINO/THERIAK program of de De Capitani and Brown (1987) [see also de Capitani (1994) and de Capitani and Petrakakis (2010)]. We chose the thermodynamic database of Berman (JUN92.bs) for moderate oxygen fugacity; at elevated oxygen fugacity (i.e., at the hematite-magnetite buffer or with oxygen in excess), we added yoderite to the dataset, which was fitted to the database. The yoderite used in the calculations contains 0.4 Fe p.f.u., which is according to Fockenberg and Schreyer (1991) its average natural composition coexisting with hematite. The thermodynamic data for S0, Cp, and volume are from Fockenberg and Schreyer (1994). $\Delta \mathrm{H} 0$ was fitted to the experimental data for the reaction yoderite + quartz $=$ talc + kyanite + hematite $+\mathrm{H}_{2} \mathrm{O}$, by the same authors. We did not incorporate carpholite and stilpnomelane in this database as their stability is restricted to low temperatures and they would hardly influence the whiteschist stability field. For similar reasons, we did not incorporate melt in the JUN92.bs database; phase diagram calculations with the Holland and Powell database tcdb55c2 including the silicatic melt LIQtc showed that the presence of melt is restricted to high and very high temperatures never affecting the whiteschist stability field (cf. Fig. S28 and Table S29).

The uncertainties in the calculated equilibrium phase diagrams depend on the accuracy of the experiments used to create the databases. These uncertainties range between $\pm 10-30{ }^{\circ} \mathrm{C}$ and $\pm 0.05-0.15 \mathrm{GPa}$; especially, reactions involving amphiboles and micas are in the upper range of these values. The solution models used in the calculations and their references are provided in Table S30 and listed in the thermodynamic databases in the electronic supplement.

In this chapter, we present the diagrams of the most typical and suitable analyses in order to illustrate the respective whiteschist stability fields of these rocks (Figs. 1, 2, 3, 4, 5, 6, 7, 8, 9, 10, 11, 12, 13, 14). Rock and mineral analyses used for the calculations of the equilibrium phase diagrams of this publication are listed in Table 1. Modal abundances of the mineral assemblages calculated for the most extended whiteschist stability fields of the investigated samples are listed in Table 2. Detailed equilibrium assemblage phase diagrams including the bulk composition used for the calculations and respective mineral reactions are given in Figures S1-S28 and Tables S2S29 of the electronic supplement. The thermodynamic databases JUN92.bs and tcdb55c2 are available in the electronic supplement. Solution models of the thermodynamic databases and respective mineral abbreviations in Tables S2-S29 are listed in Table S30. 


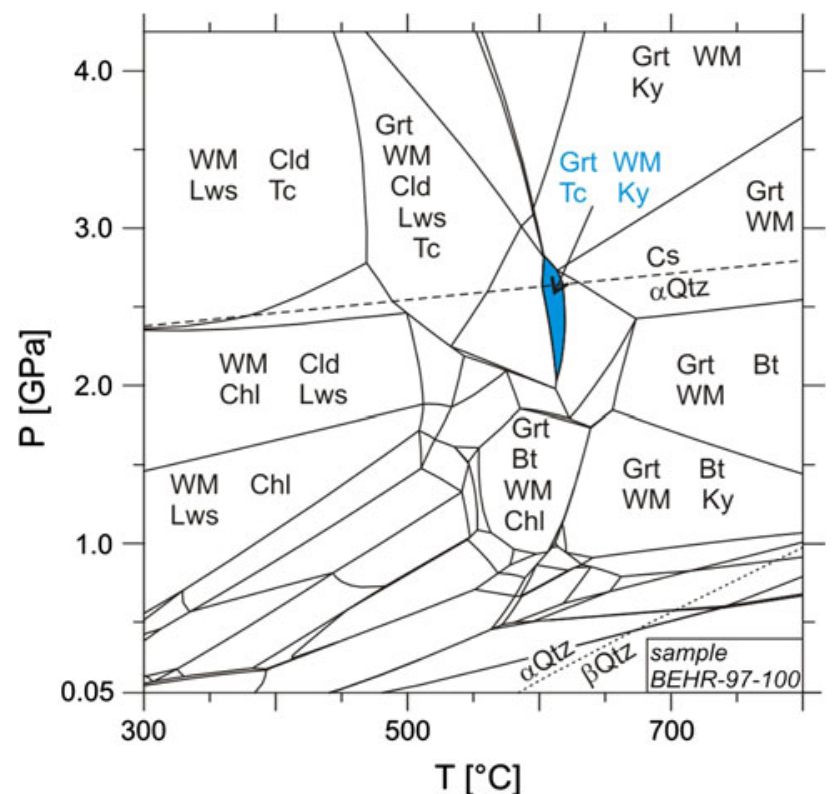

Fig. 1 Equilibrium phase diagram of Mg-rich pelite sample BEHR97-100 (Hahne, unpubl.); $\mathrm{H}_{2} \mathrm{O}$ and $\mathrm{SiO}_{2}$ in excess, whiteschist stability field is marked blue, mineral abbreviations after Kretz (1983) and Spear (1993)

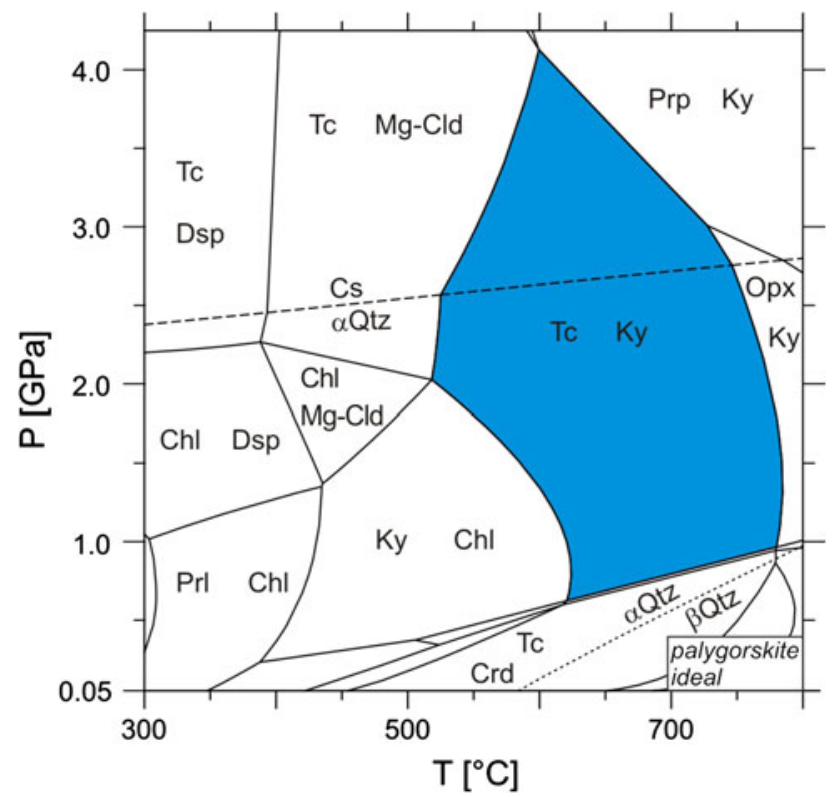

Fig. 2 Equilibrium phase diagram of palygorskite (ideal formula); $\mathrm{H}_{2} \mathrm{O}$ and $\mathrm{SiO}_{2}$ in excess, legend see Fig. 1

\section{Pelitic rocks}

\section{Mg-rich KFMASH and KMASH rocks}

To generate a whiteschist from sedimentary protoliths, rocks with a primary $\mathrm{Al}$ - and $\mathrm{Mg}$-rich, $\mathrm{Ca}$ - and alkali-poor composition are needed. Furthermore, these sediments must

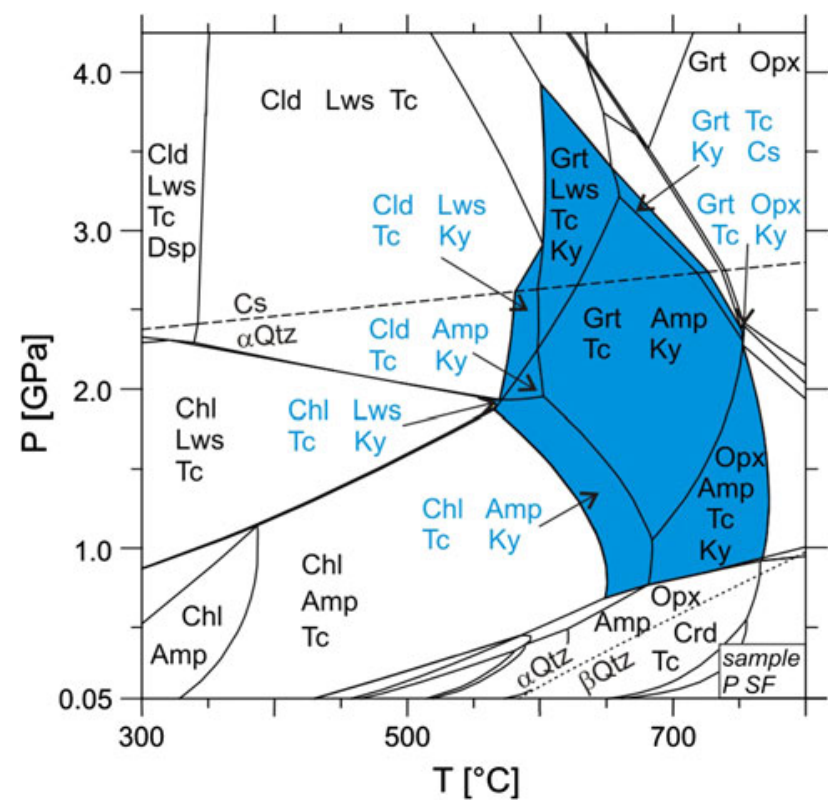

Fig. 3 Equilibrium phase diagram of palygorskite sample P SF from Springbok Flats (Heystek and Schmidt 1953); $\mathrm{H}_{2} \mathrm{O}$ and $\mathrm{SiO}_{2}$ in excess, legend see Fig. 1

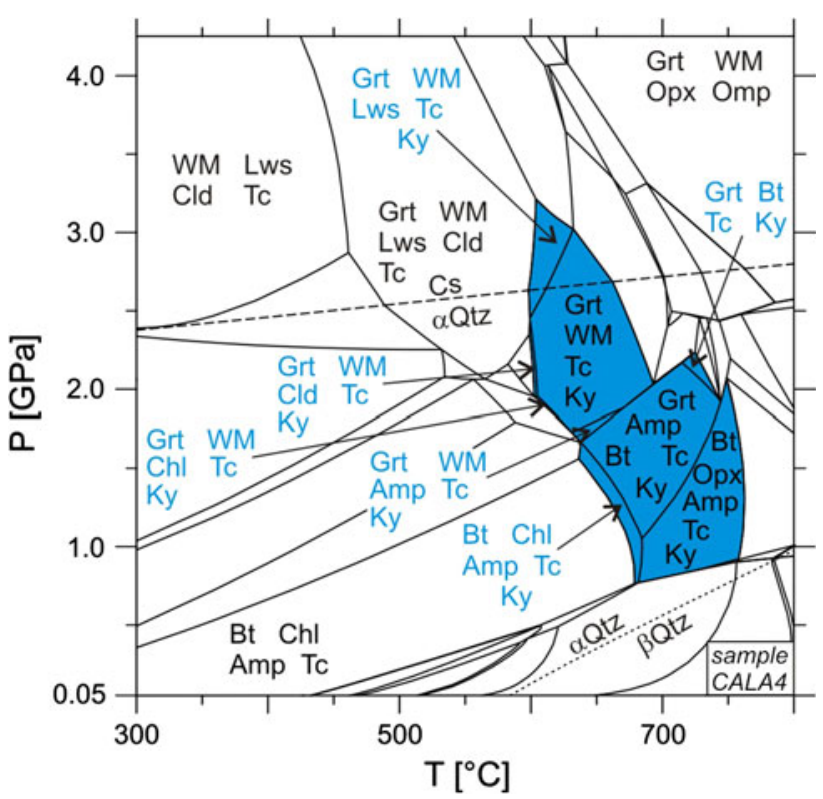

Fig. 4 Equilibrium phase diagram of pelite sample CALA4 from the Spanish Tertiary Basin (Torres-Ruiz' et al. 1994); $\mathrm{H}_{2} \mathrm{O}$ and $\mathrm{SiO}_{2}$ in excess, legend see Fig. 1

be subducted to reach at least the high-pressure low- to medium-temperature regime where whiteschist assemblages are stable. High Al-contents are preferably found in pelitic sediments. However, most of these rocks have far too high iron contents and contain considerable amounts of alkali elements and $\mathrm{Ca}$. Marine clays above the $\mathrm{CCD}$, for example, accumulate Ca-rich globigerina mud, while deep- 


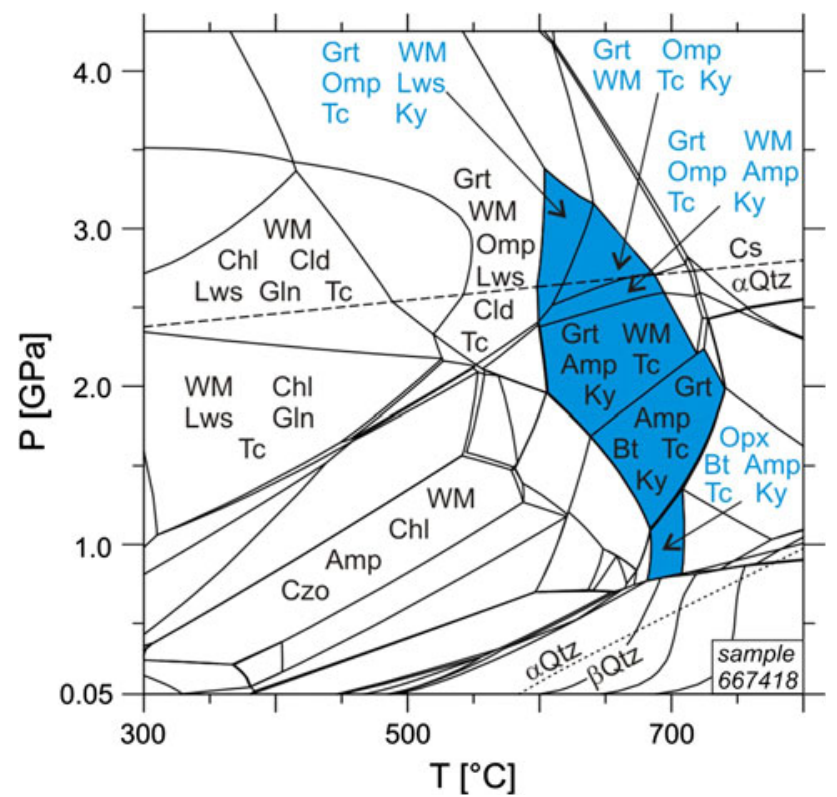

Fig. 5 Equilibrium phase diagram of pelite sample 667418 from an evaporitic succession (Moine et al. 1981) $\mathrm{H}_{2} \mathrm{O}$ and $\mathrm{SiO}_{2}$ in excess, legend see Fig. 1

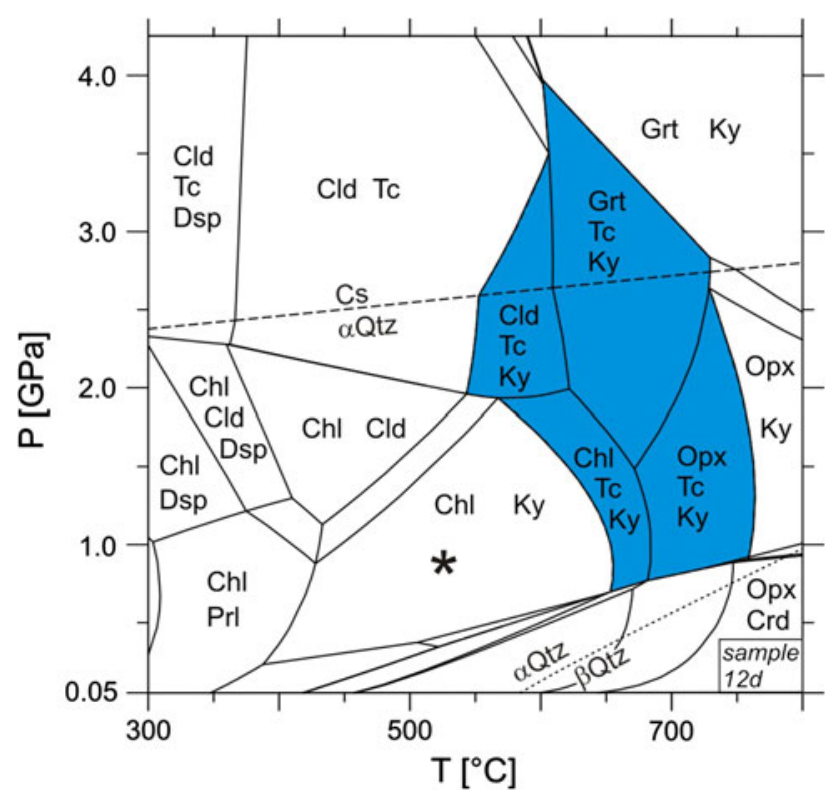

Fig. 6 Equilibrium phase diagram of metasomatic paragneiss sample 12d from the Rabenwald talc deposit (Moine et al. 1989); $\mathrm{H}_{2} \mathrm{O}$ and $\mathrm{SiO}_{2}$ in excess, legend see Fig. 1

sea clays often accumulate iron from eolian dust (loess or volcanic ash), terrigeneous input (e.g., by rivers) or debris from weathered oceanic basalts (see Ziegler et al. 2008; Radic et al. 2011 and citations within). Elevated Mg contents are found in oceanic sediments with high sedimentation rates (i.e., turbidites; cf. Plank and Langmuir 1998) and in marine or non-marine evaporites (e.g., Moine

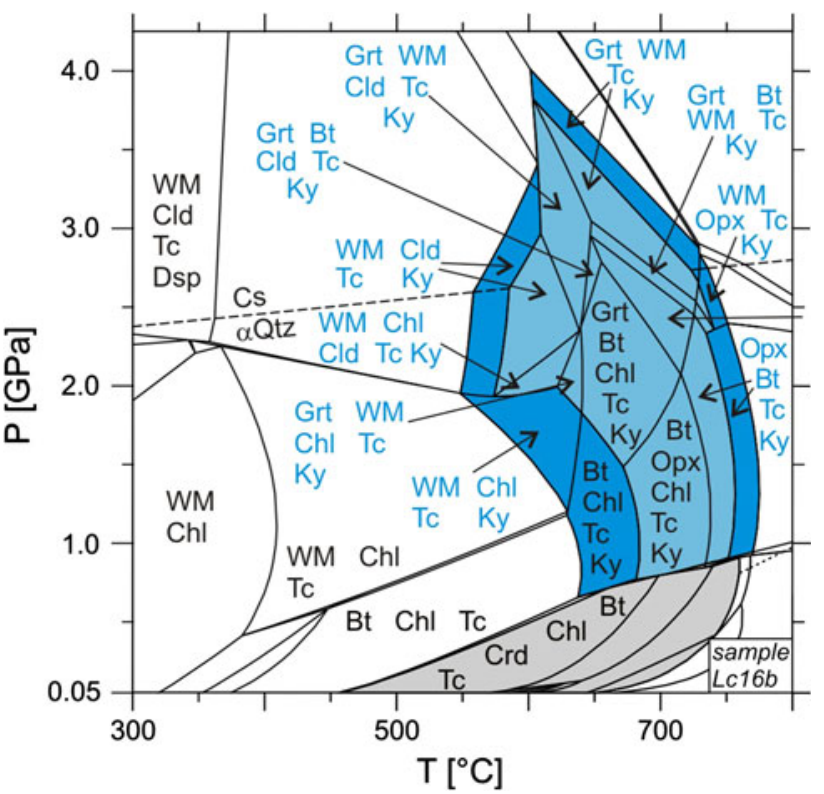

Fig. 7 Equilibrium phase diagram of metasomatic quartz-chlorite schist sample Lc16b from the Trimouns talc and chlorite deposit (Moine et al. 1989); $\mathrm{H}_{2} \mathrm{O}$ in excess, quartz- and coesite-bearing whiteschist assemblages are marked in cyan color, quartz- and coesite-free whiteschist assemblages are marked in light blue color; quartz-free non-whiteschist assemblages are marked in gray

et al. 1981; Warren 2010). Phase diagram calculations show that the chemical composition of marine pelitic sediments from converging margins [data from Plank and Langmuir (1998)] is not suitable for generating whiteschists. These rocks are mainly composed of clay, chert, calcareous, and siliceous ooze and silt/sand components and usually have elevated $\mathrm{Fe}$ and alkali contents and low $\mathrm{Mg}$ contents. Even turbidites with volcanogenic components and, thus, high $\mathrm{Mg}$ concentrations do not yield talc-kyanite-bearing mineral assemblages.

Early Ordovician and Permian to Triassic shales from the Schwarzburg area (Germany) have been deposited in continental, shallow marine, and deep marine settings (Romer and Hahne 2010). These rocks are characterized by profound chemical weathering followed by redeposition in shallow marine and fluvial to arid environments, respectively. Phase diagram calculations of $68 \mathrm{Mg}$-rich metapelites covering the entire profile were performed with only one sample from a semi-closed evaporite basin (BEHR-97100) showing a narrow whiteschist stability field at 600-620 ${ }^{\circ} \mathrm{C}$ and $2.0-2.8 \mathrm{GPa}$. The whiteschist mineral assemblages are garnet-white mica-talc-kyanite-coesite and garnet-white mica-talc-kyanite-quartz (Fig. 1, Fig. S1, Table S2). However, the chance for a rock to equilibrate in this limited stability field and to preserve the whiteschist mineral assemblage during exhumation is very small (Fig. 1). Furthermore, the rock could hardly be recognized as a whiteschist in the field due to the low modal amount of 


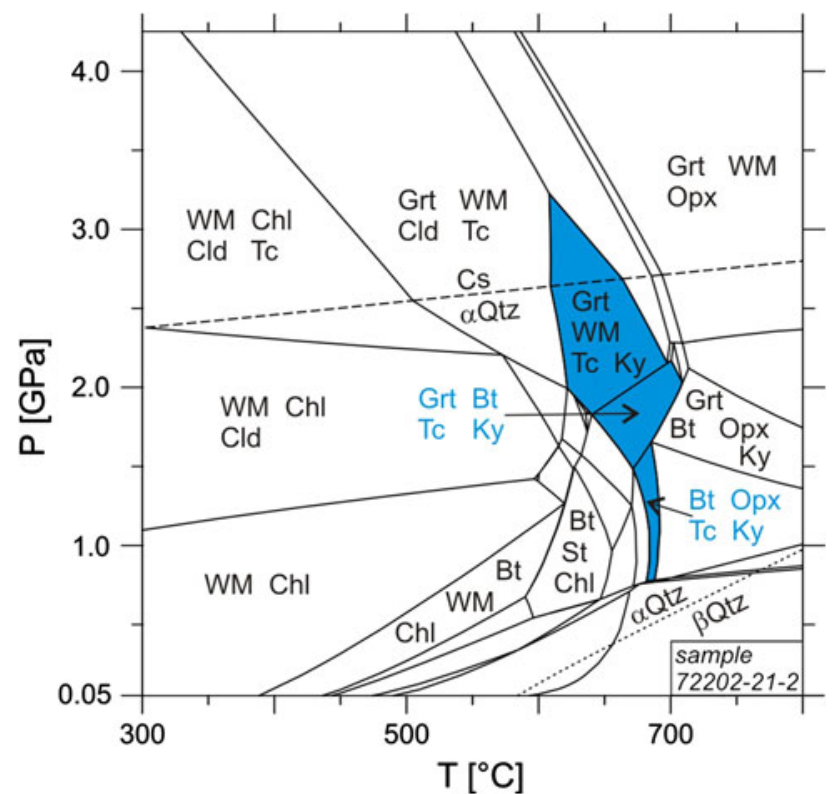

Fig. 8 Equilibrium phase diagram of metavolcanic chlorite schist sample 72202-21-2 from the Kristineberg VMS deposit (Hannington et al. 2003); $\mathrm{H}_{2} \mathrm{O}$ and $\mathrm{SiO}_{2}$ in excess, legend see Fig. 1

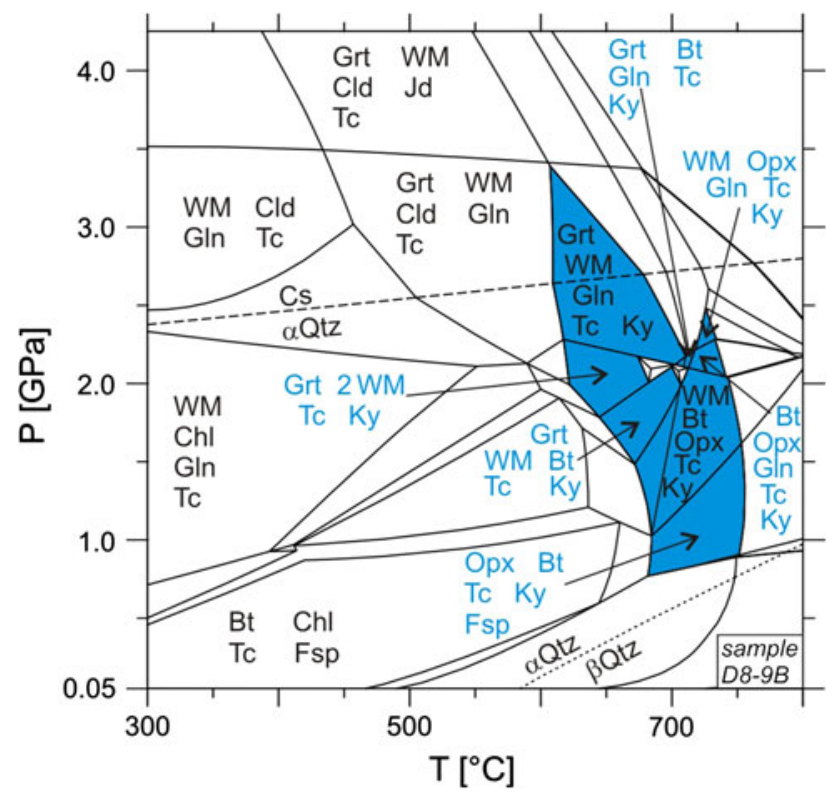

Fig. 9 Equilibrium phase diagram of hydrothermal palygorskite vein sample D8-9B from the central California margin fracture zone (Gibbs et al. 1993); $\mathrm{H}_{2} \mathrm{O}$ and $\mathrm{SiO}_{2}$ in excess, legend see Fig. 1

talc ( $\sim 4$ vol. $\%)$ and kyanite $(\sim 0.5$ vol.\%) generated in its whiteschist stability field (cf. Table 2).

This modeling indicates that shales typically have too low $\mathrm{MgO}$ and/or too high $\mathrm{CaO}, \mathrm{FeO}$, and $\mathrm{Na}_{2} \mathrm{O}$ contents to produce stable whiteschist mineral assemblages. Even shelf sediments that experienced extreme geochemical weathering and recycling of weathered material,

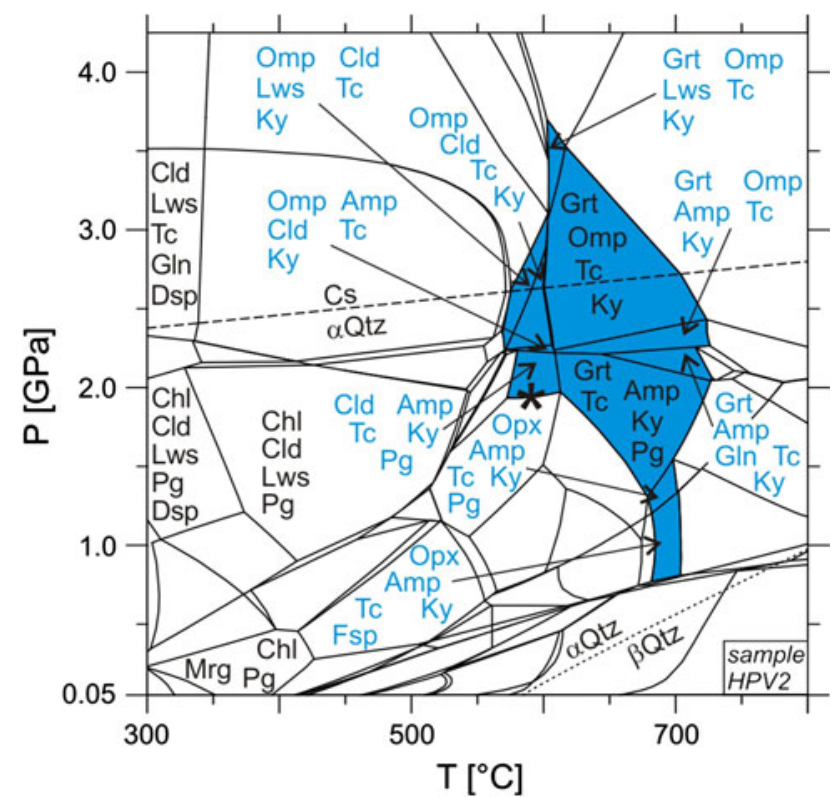

Fig. 10 Equilibrium phase diagram of high-pressure quartz vein sample HPV2 from Dabie Shan; asterisk indicates metamorphic P-T conditions of the vein (cf. Franz et al. 2001); $\mathrm{H}_{2} \mathrm{O}$ and $\mathrm{SiO}_{2}$ in excess, legend see Fig. 1

characterized by depletion in $\mathrm{Ca}$ and $\mathrm{Na}$ do not have compositions favorable for the formation of whiteschist.

\section{Palygorskite-bearing pelites}

Most pelites from continental and marine environments have elevated $\mathrm{Fe}$ contents. High $\mathrm{Fe}$ contents, however, stabilize chloritoid, which is the main reason for the absence of talc in metamorphic equivalents of pelites. There are, however, pelitic rocks with low Fe contents and high concentrations of $\mathrm{Mg}$, which is mainly due to high modal amounts of palygorskite, an Al- and Mg-rich clay mineral with the general mineral formula

$$
\begin{aligned}
& \left(\mathrm{Mg}_{5-y-z} \mathrm{R}_{y-z}^{3+}\right)_{\text {oct }}\left(\mathrm{Si}_{8-x} \mathrm{R}_{x}^{3+}\right)_{\text {tet }} \mathrm{O}_{20}(\mathrm{OH})_{2}\left(\mathrm{H}_{2} \mathrm{O}\right)_{4} \mathrm{R}_{(x-y+2 z) / 2}^{2+} \\
& \quad * 4 \mathrm{H}_{2} \mathrm{O}
\end{aligned}
$$

(Bish and Guthrie 1993). The trivalent cation $\mathrm{R}^{3+}$ is $\mathrm{Al}$ or Fe. The bivalent cation $\mathrm{R}^{2+}$ is exchangeable (usually $\mathrm{Ca}$ but also $\mathrm{Na}$ or $\mathrm{K}$ ). The simplified ideal mineral formula of palygorskite is $(\mathrm{Mg}, \mathrm{Al})_{4} \mathrm{Si}_{8} \mathrm{O}_{20}(\mathrm{OH})_{2} * 8 \mathrm{H}_{2} \mathrm{O}$. Together with other clay minerals like montmorillonite and sepiolite, palygorskite-formerly also termed attapulgite-forms part of the so-called fuller's earth, which is an important absorbent and filter in industrial and technical processes. Palygorskite mainly occurs in shallow marine or lacustrine sediments and furthermore in arid and saline environments [for reviews see Singer (1979) and de Pablo-Galán (1996)]. Large palygorskite deposits are located in South Georgia 


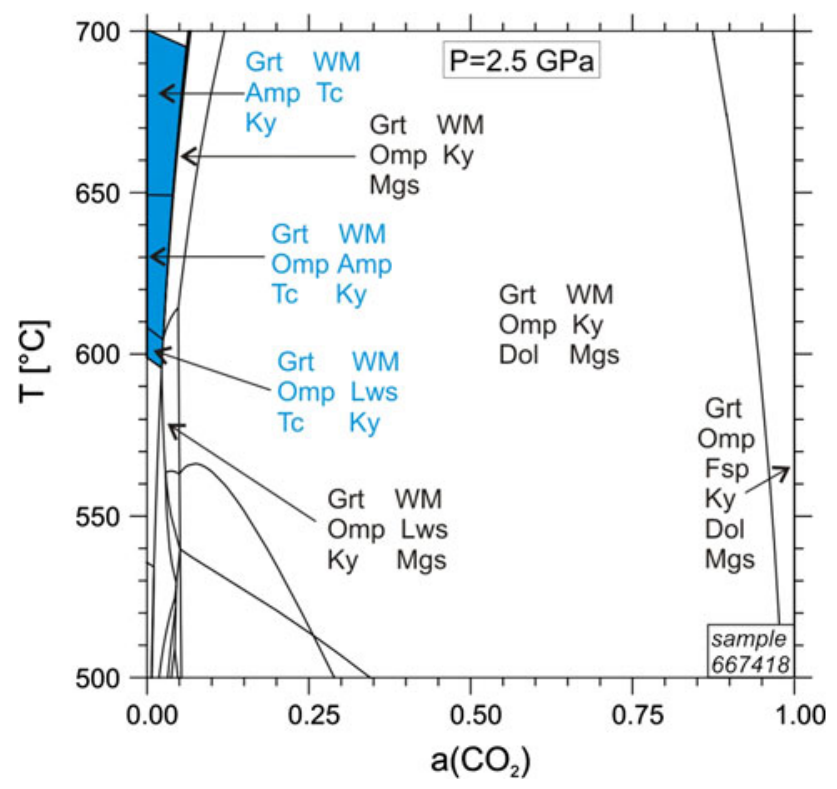

Fig. 11 Phase diagram showing $\mathrm{T}$ versus $\mathrm{a}\left(\mathrm{CO}_{2}\right)$ of pelite sample 667418 (Moine et al. 1981); $\mathrm{H}_{2} \mathrm{O}, \mathrm{CO}_{2}$ and $\mathrm{SiO}_{2}$ in excess, legend see Fig. 1

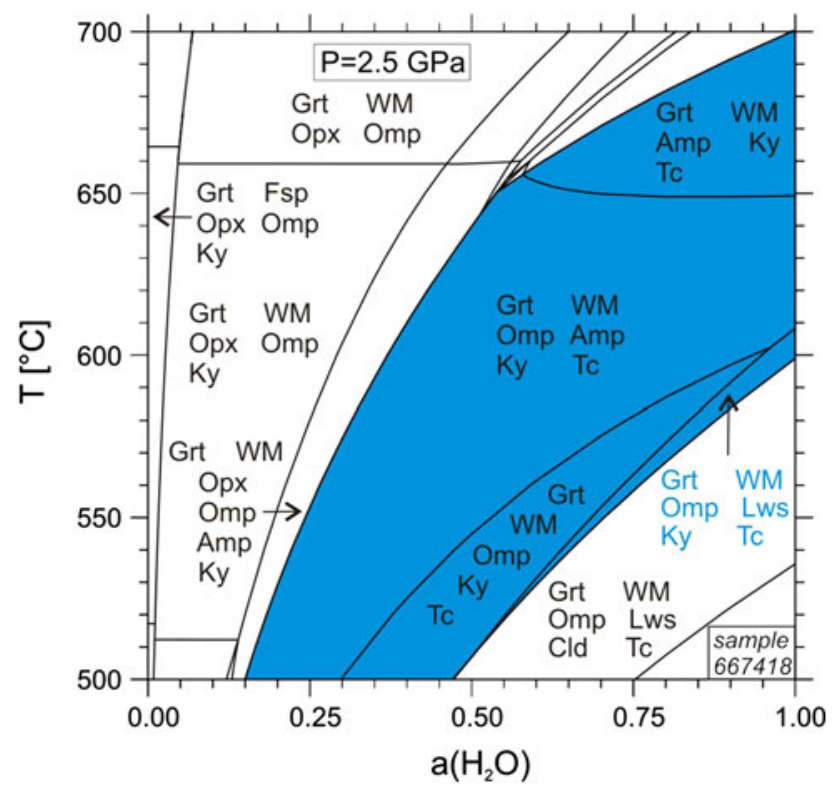

Fig. 12 Phase diagram showing $\mathrm{T}$ versus $\mathrm{a}\left(\mathrm{H}_{2} \mathrm{O}\right)$ of pelite sample 667418 (Moine et al. 1981); $\mathrm{H}_{2} \mathrm{O}$ and $\mathrm{SiO}_{2}$ in excess, legend see Fig. 1

and North Florida (shallow marine type), in central and northern Spain and in western Macedonia of Greece (continental type), in Senegal (epicontinental marine type), and in Guanshan in China [fluvial and lacustrine type; for a review of these deposits see Murray et al. (2011)]. In these deposits, palygorskite layers with thicknesses of 4-8 $\mathrm{m}$ are regularly observed. Palygorskite may form by dissolutionprecipitation or by neoformation processes (Isphording

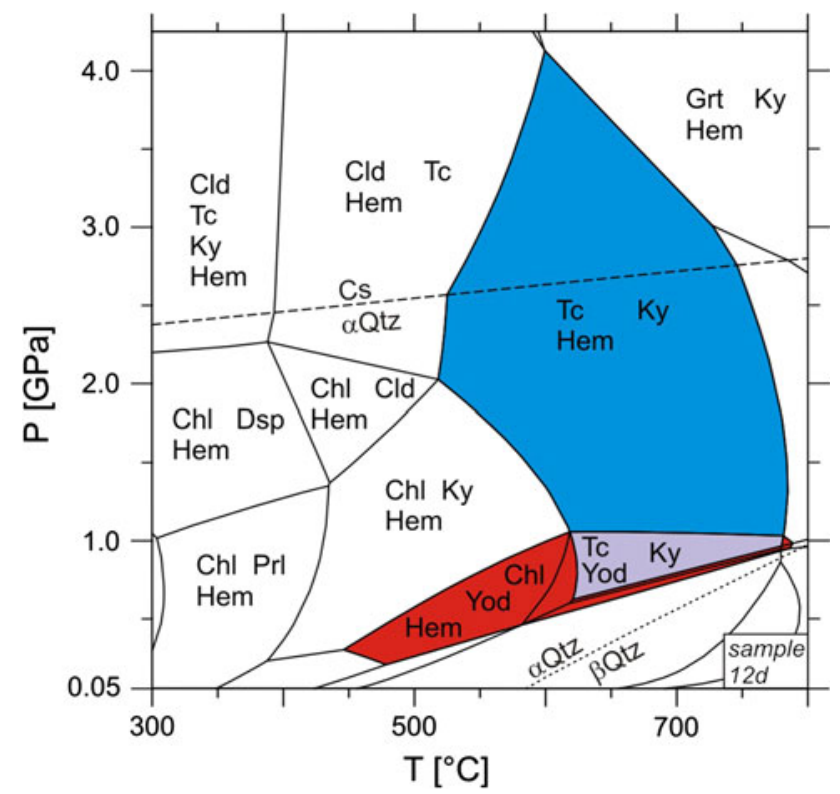

Fig. 13 Equilibrium phase diagram of metasomatic paragneiss sample 12d from the Rabenwald talc deposit (Moine et al. 1989) calculated with $\mathrm{O}, \mathrm{H}_{2} \mathrm{O}$ and $\mathrm{SiO}_{2}$ in excess; yoderite-bearing whiteschist assemblages are marked in light violet color and nonwhiteschist yoderite assemblages marked in red color; legend see Fig. 1

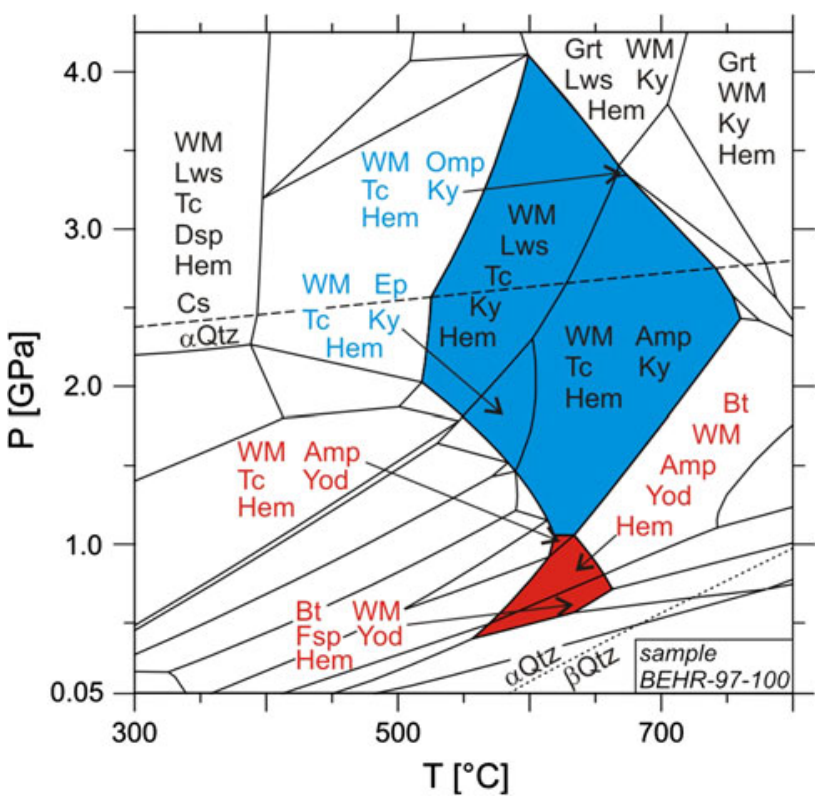

Fig. 14 Equilibrium phase diagram of Mg-rich pelite sample BEHR97-100 calculated with $\mathrm{O}, \mathrm{H}_{2} \mathrm{O}$, and $\mathrm{SiO}_{2}$ in excess; yoderite-bearing assemblages are marked red; legend see Fig. 1

1973, 1984), by transformation of illite, smectite, or sepiolite (Rogers et al. 1954; Galán and Castillio 1984; Singer 1984; Sánchez and Galán 1995), by reaction involving montmorillonite, dolomite, and silicates (e.g., Jones 1986), 
Table 1 Geochemical whole rock and mineral analyses of the investigated samples with references to the respective figures of their equilibrium phase diagrams

\begin{tabular}{|c|c|c|c|c|c|c|c|c|c|c|c|}
\hline $\begin{array}{l}\text { Sample } \\
\text { Rock type }\end{array}$ & $\begin{array}{l}\text { BEHR-97-100 } \\
\text { Figs. 1, 14, S1, } \\
\text { S24-25 }\end{array}$ & $\begin{array}{l}\text { P SF } \\
\text { Fig. 3, S3 }\end{array}$ & $\begin{array}{l}\text { P Yu } \\
\text { Fig. S4 }\end{array}$ & $\begin{array}{l}\text { P Ip } \\
\text { Fig. S5 }\end{array}$ & \multicolumn{2}{|c|}{$\begin{array}{l}\text { 70:30 S RC } \\
\text { Fig. S6 }\end{array}$} & $\begin{array}{l}\text { CALA4 } \\
\text { Fig. } 4, \text { S7 }\end{array}$ & $\begin{array}{l}667418 \\
\text { Figs. 5, 11, 12, S8, } \\
\text { S19-21, S28 }\end{array}$ & \multicolumn{2}{|c|}{$\begin{array}{l}\text { 12d } \\
\text { Figs. 6, 13, S9, } \\
\text { S22-23 }\end{array}$} & $\begin{array}{l}42 \mathrm{a} \\
\text { Fig. S10 }\end{array}$ \\
\hline $\mathrm{SiO}_{2}$ & 52.18 & 61.60 & 53.75 & 59.09 & 46.90 & & 59.50 & 50.04 & 52.05 & & 62.43 \\
\hline $\mathrm{TiO}_{2}$ & 0.81 & 0.00 & 0.31 & 0.99 & 0.38 & & 0.22 & 0.94 & 1.46 & & 0.21 \\
\hline $\mathrm{Al}_{2} \mathrm{O}_{3}$ & 20.06 & 6.82 & 11.56 & 6.84 & 10.40 & & 6.43 & 14.29 & 21.86 & & 19.40 \\
\hline $\mathrm{Cr}_{2} \mathrm{O}_{3}$ & 0.00 & 0.00 & 0.00 & 0.00 & 0.00 & & 0.00 & 0.00 & 0.00 & & 0.00 \\
\hline $\mathrm{Fe}_{2} \mathrm{O}_{3}$ & 6.35 & 0.87 & 1.78 & 4.21 & 2.68 & & 2.09 & 5.09 & 1.83 & & 0.56 \\
\hline $\mathrm{P}_{2} \mathrm{O}_{5}$ & 0.16 & 0.00 & 0.00 & 0.00 & 0.00 & & 0.00 & 0.00 & 0.05 & & 0.41 \\
\hline $\mathrm{MgO}$ & 7.16 & 14.22 & 10.41 & 14.12 & 16.20 & & 19.71 & 16.36 & 15.73 & & 7.35 \\
\hline $\mathrm{CaO}$ & 1.01 & 0.67 & 0.98 & 0.00 & 0.45 & & 0.66 & 2.61 & 0.00 & & 0.34 \\
\hline $\mathrm{MnO}$ & 0.03 & 0.00 & 0.00 & 0.00 & 0.00 & & 0.02 & 0.01 & 0.03 & & 0.02 \\
\hline $\mathrm{FeO}$ & 0.00 & 0.00 & 0.34 & 0.00 & 0.00 & & 0.00 & 0.00 & 0.00 & & 0.00 \\
\hline $\mathrm{BaO}$ & 0.00 & 0.00 & 0.00 & 0.00 & 0.00 & & 0.00 & 0.00 & 0.00 & & 0.00 \\
\hline $\mathrm{Na}_{2} \mathrm{O}$ & 0.17 & 0.00 & 0.63 & 0.00 & 0.41 & & 0.05 & 0.08 & 0.00 & & 0.37 \\
\hline $\mathrm{K}_{2} \mathrm{O}$ & 6.40 & 0.00 & 0.62 & 0.00 & 0.11 & & 1.37 & 0.87 & 0.04 & & 4.80 \\
\hline LOI & 5.00 & 14.16 & 19.41 & 14.18 & 20.33 & & 9.96 & 10.35 & 6.76 & & 4.32 \\
\hline Total & 99.34 & 98.34 & 99.79 & 99.43 & 97.88 & & 100.01 & 100.64 & 99.81 & & 100.21 \\
\hline$X_{M g}$ & 0.69 & 0.97 & 0.91 & 0.87 & 0.92 & & 0.95 & 0.86 & 0.94 & & 0.96 \\
\hline $\mathrm{AM} / \mathrm{FCNK}$ & 2.4 & 21.3 & 6.2 & 9.2 & 10.6 & & 9.0 & 5.2 & 34.5 & & 4.4 \\
\hline AS/FCNK & 5.3 & 50.7 & 14.4 & 21.2 & 17.2 & & 16.3 & 8.5 & 54.5 & & 11.2 \\
\hline Sample & Lc16b & Lc16d & 72202-21- & & KIB-6B & D8- & $9 \mathrm{~B}$ & PJ02-5B & $\begin{array}{l}\text { HPV2 } \\
\end{array}$ & Loc\& & $\begin{array}{l}800 \\
\mathrm{~S} 26 \mathrm{~S} 27\end{array}$ \\
\hline Rock type & Fig. 7, S11 & Fig. S12 & Fig. 8, S1 & & Fig. S14 & Fig & $9, \mathrm{~S} 15$ & Figs. S16, S17 & Fig. 10, S18 & Figs & . S26, S27 \\
\hline $\mathrm{SiO}_{2}$ & 51.40 & 34.40 & 62.70 & & 68.80 & 55. & & 28.23 & 85.76 & 54. & 15 \\
\hline $\mathrm{TiO}_{2}$ & 0.10 & 0.20 & 0.36 & & 0.50 & 0. & & 0.03 & 0.38 & 1. & 28 \\
\hline $\mathrm{Al}_{2} \mathrm{O}_{3}$ & 13.51 & 18.98 & 11.20 & & 10.75 & 5.5 & & 17.84 & 8.02 & 8. & 59 \\
\hline $\mathrm{Cr}_{2} \mathrm{O}_{3}$ & 0.00 & 0.00 & 0.00 & & 0.00 & $0 .($ & & 0.00 & 0.00 & 0. & 00 \\
\hline $\mathrm{Fe}_{2} \mathrm{O}_{3}$ & 1.25 & 1.59 & 1.10 & & 2.60 & 2.2 & & 0.00 & 0.07 & 0. & 00 \\
\hline $\mathrm{P}_{2} \mathrm{O}_{5}$ & 0.00 & 0.00 & 0.08 & & 0.10 & 0. & & 0.00 & 0.00 & 0. & 24 \\
\hline $\mathrm{MgO}$ & 23.75 & 33.03 & 12.66 & & 7.18 & 15.2 & & 27.88 & 3.27 & 8. & 72 \\
\hline $\mathrm{CaO}$ & 0.05 & 0.16 & 0.12 & & 0.45 & 0. & & 0.18 & 0.95 & 3. & 97 \\
\hline $\mathrm{MnO}$ & 0.02 & 0.04 & 0.23 & & 0.10 & 0. & & 0.08 & 0.01 & 0 . & 15 \\
\hline $\mathrm{FeO}$ & 0.00 & 0.00 & 5.50 & & 0.10 & 0. & & 11.09 & 0.80 & 8. & 59 \\
\hline $\mathrm{BaO}$ & 0.00 & 0.00 & 0.00 & & 0.00 & 0. & & 0.00 & 0.00 & 0 . & 00 \\
\hline $\mathrm{Na}_{2} \mathrm{O}$ & 0.00 & 0.00 & 0.00 & & 0.01 & 0.3 & & 0.00 & 0.30 & 1. & 80 \\
\hline $\mathrm{K}_{2} \mathrm{O}$ & 0.37 & 0.09 & 0.25 & & 1.00 & 0.3 & & 0.00 & 0.00 & 1. & 74 \\
\hline LOI & 8.88 & 12.22 & 6.00 & & 7.25 & 20. & & 12.45 & 0.45 & 10. & 94 \\
\hline Total & 99.33 & 100.71 & 100.12 & & 98.84 & 99. & & 97.78 & 100.00 & 100. & \\
\hline$X_{M g}$ & 0.97 & 0.98 & 0.78 & & 0.84 & 0. & & 0.82 & 0.87 & 0 . & 64 \\
\hline $\mathrm{AM} / \mathrm{FCNK}$ & 35.0 & 48.3 & 5.5 & & 6.1 & 9.3 & & 6.6 & 6.1 & 1. & 3 \\
\hline AS/FCNK & 45.9 & 38.3 & 12.9 & & 21.3 & 19. & & 5.2 & 40.8 & 3. & 7 \\
\hline
\end{tabular}

Values for $\mathrm{X}_{\mathrm{Mg}}\left(=\mathrm{Mg} /\left(\mathrm{Mg}+\mathrm{Fe}^{2+}\right)\right), \mathrm{AM} / \mathrm{FCNK}\left(=(\mathrm{Al}+\mathrm{Mg}) /\left(\mathrm{Fe}^{2+}+\mathrm{Ca}+\mathrm{Na}+\mathrm{K}\right)\right)$ and $\mathrm{AS} / \mathrm{FCNK}\left(=(\mathrm{Al}+\mathrm{Si}) /\left(\mathrm{Fe}^{2+}+\mathrm{Ca}+\mathrm{Na}+\mathrm{K}\right)\right)$ are listed below

or by alteration of serpentine minerals (Dhannoun and AlDabbagh 1988). Furthermore, it can form by hydrothermal alteration of montmorillonite-group clays (Bonatti and Joensuu 1968) or in hydrothermal veins in mafic rocks (e.g., Gibbs et al. 1993). Phase diagram calculation using an ideal formula for palygorskite $\left(\mathrm{Mg}_{2} \mathrm{Al}_{2} \mathrm{Si}_{8} \mathrm{O}_{20}(\mathrm{OH})_{2}\right.$ $* 8 \mathrm{H}_{2} \mathrm{O}$ ) reveals a wide stability field for whiteschist assemblages ranging from 510 to $780{ }^{\circ} \mathrm{C}$ at $0.6-4.1 \mathrm{GPa}$ 
Table 2 Modal mineral content of the samples (vol.\%) at given $\mathrm{P}, \mathrm{T}, \mathrm{a}\left(\mathrm{H}_{2} \mathrm{O}\right)$, and $\mathrm{f}\left(\mathrm{O}_{2}\right)$

\begin{tabular}{|c|c|c|c|c|c|c|c|c|c|c|}
\hline Sample & \multicolumn{2}{|c|}{ Rock type } & $\mathrm{P}(\mathrm{GPa})$ & $\mathrm{T}\left({ }^{\circ} \mathrm{C}\right)$ & $\mathrm{a}\left(\mathrm{H}_{2} \mathrm{O}\right)$ & $\mathrm{f}\left(\mathrm{O}_{2}\right)$ & $\mathrm{Tc}$ & $\mathrm{Ky}$ & Qtz & Grt \\
\hline BEHR-97-100 & \multicolumn{2}{|c|}{ Mg-rich shale } & 2.5 & 610 & 1 & sat. & 4.1 & 0.5 & 12.5 & 21.8 \\
\hline BEHR-97-100 & \multicolumn{2}{|c|}{ Mg-rich shale } & 2.5 & 610 & 1 & OHM & 4.1 & 0.5 & 12.5 & 21.8 \\
\hline BEHR-97-100 & \multicolumn{2}{|c|}{ Mg-rich shale } & 2.5 & 610 & 1 & $\mathrm{O}$ in exc. & 15.2 & 6.4 & 11.6 & - \\
\hline Palygorskite & \multicolumn{2}{|c|}{ Ideal } & 2.2 & 670 & 1 & sat. & 39.1 & 19.3 & 41.6 & - \\
\hline P SF & \multicolumn{2}{|c|}{ Palygorskite-rich clay } & 2.2 & 690 & 1 & sat. & 47.1 & 7.8 & 36.5 & 5.8 \\
\hline $\mathrm{P} \mathrm{Yu}$ & \multicolumn{2}{|c|}{ Palygorskite-rich clay } & 2.3 & 680 & 1 & sat. & 29.4 & 9.8 & 32.2 & 12.9 \\
\hline P Ip & \multicolumn{2}{|c|}{ Palygorskite-rich clay } & 1.6 & 700 & 1 & sat. & 22.1 & 10.1 & 37.3 & - \\
\hline 70:30 S RC & \multicolumn{2}{|c|}{$70 \%$ sepiolite \& $30 \%$ clay } & 2.3 & 690 & 1 & sat. & 52.0 & 9.2 & 13.3 & 19.1 \\
\hline CALA4 & \multicolumn{2}{|c|}{ Sepiolite-illite-quartz-clay } & 1.7 & 680 & 1 & sat. & 52.5 & 4.3 & 21.3 & 6.4 \\
\hline 667418 & \multicolumn{2}{|c|}{ Mg-chlorite-illite-argillite } & 2.2 & 630 & 1 & sat. & 43.1 & 9.4 & 7.5 & 21.8 \\
\hline 667418 & \multicolumn{2}{|c|}{ Mg-chlorite-illite-argillite } & 2.2 & 600 & 0.6 & sat. & 40.6 & 9.5 & 7.7 & 21.9 \\
\hline $12 \mathrm{~d}$ & \multicolumn{2}{|c|}{ Metasomatic paragneiss } & 2.2 & 660 & 1 & sat. & 53.0 & 28.9 & 10.4 & 7.7 \\
\hline $12 \mathrm{~d}$ & \multicolumn{2}{|c|}{ Metasomatic paragneiss } & 2.2 & 660 & 1 & OHM & 53.0 & 28.9 & 10.4 & 7.7 \\
\hline $12 \mathrm{~d}$ & \multicolumn{2}{|c|}{ Metasomatic paragneiss } & 2.2 & 660 & 1 & $\mathrm{O}$ in exc. & 57.8 & 31.4 & 9.6 & - \\
\hline $42 \mathrm{a}$ & \multicolumn{2}{|c|}{ Metasomatic orthogneiss } & 2.4 & 620 & 1 & sat. & 16.1 & 6.5 & 28.5 & 0.9 \\
\hline Lc16b & \multicolumn{2}{|c|}{ Metasomatic micaschist } & 2.2 & 660 & 1 & sat. & 70.6 & 14.9 & - & 4.0 \\
\hline Lc16d & Chlorite & & 1.8 & 660 & 1 & sat. & 9.7 & 1.3 & - & - \\
\hline $72202-21-2$ & hyd. alte & Icanic & 2.0 & 650 & 1 & sat. & 28.6 & 5.1 & 37.9 & 26.0 \\
\hline KIB-6B & Argilliti & & 2.0 & 640 & 1 & sat. & 18.9 & 8.1 & 53.9 & 9.6 \\
\hline D8-9B & Palygors & & 1.8 & 700 & 1 & sat. & 38.5 & 5.0 & 29.8 & - \\
\hline РJ02-5B & $75 \% \mathrm{ch}$ & $5 \%$ Qtz & 2.0 & 650 & 1 & sat. & 51.6 & 4.7 & - & 38.3 \\
\hline HPV2 & HP-quar & & 2.4 & 650 & 1 & sat. & 6.3 & 8.0 & 77.5 & 3.7 \\
\hline Loc800 & Mg-rich & & 2.6 & 650 & 1 & sat. & - & - & 21.3 & 9.4 \\
\hline Loc800 & Mg-rich & & 2.6 & 650 & 1 & $\mathrm{O}$ in exc. & 19.6 & 2.8 & 24.8 & - \\
\hline Sample & $\mathrm{WM}$ & Amp & Omp & Gln & Opx & $\mathrm{Bt}$ & Chl & & Lws & $\mathrm{Ht}$ \\
\hline BEHR-97-100 & 61.1 & - & - & - & - & - & - & & - & - \\
\hline BEHR-97-100 & 61.1 & - & - & - & - & - & - & & - & - \\
\hline BEHR-97-100 & 58.5 & - & - & - & - & - & - & & 4.5 & 3.8 \\
\hline Palygorskite & - & - & - & - & - & - & - & & - & - \\
\hline P SF & - & 2.8 & - & - & - & - & - & & - & - \\
\hline P Yu & 7.1 & - & 6.9 & 1.7 & - & - & - & & - & - \\
\hline P Ip & - & - & - & - & 30.5 & - & - & & - & - \\
\hline 70:30 S RC & - & - & 1.3 & 5.1 & - & - & - & & - & - \\
\hline CALA4 & - & 1.9 & - & - & - & 13.6 & - & & - & - \\
\hline 667418 & 8.9 & 9.3 & - & - & - & - & - & & - & - \\
\hline 667418 & 8.9 & 11.4 & - & - & - & - & - & & - & - \\
\hline $12 \mathrm{~d}$ & - & - & - & - & - & - & - & & - & - \\
\hline $12 \mathrm{~d}$ & - & - & - & - & - & - & - & & - & - \\
\hline $12 \mathrm{~d}$ & - & - & - & - & - & - & - & & - & 1.2 \\
\hline $42 \mathrm{a}$ & 44.2 & - & - & 3.8 & - & - & - & & - & - \\
\hline Lc16b & - & - & - & - & - & 3.7 & 6.8 & & - & - \\
\hline Lc16d & - & 1.0 & - & - & - & 0.8 & 87.2 & & - & - \\
\hline $72202-21-2$ & 2.4 & - & - & - & - & - & - & & - & - \\
\hline KIB-6B & 9.5 & - & - & - & - & - & - & & - & - \\
\hline D8-9B & 5.7 & - & - & - & 17.2 & 3.8 & - & & - & - \\
\hline PJ02-5B & & - & - & - & - & - & 5.4 & & - & - \\
\hline HPV2 & - & - & 4.5 & - & - & - & - & & - & - \\
\hline Loc800 & 18.8 & - & 28.6 & - & 21.9 & - & - & & - & - \\
\hline Loc800 & 18.0 & - & 28.4 & - & - & - & - & & - & 6.4 \\
\hline
\end{tabular}

The given modal abundances were calculated for the central point of the most extended whiteschist stability field of each rock and may vary considerably across the field $O$ in exc. oxygen in excess, $O H M$ hematite-magnetite oxygen buffer, sat. ferrous iron only 
with the mineral assemblages talc-kyanite-quartz and talckyanite-coesite (Fig. 2, Fig. S2, Table S3). The rock yields prominent modal amounts of talc and kyanite ( $>58$ vol.\%; see Table 2).

To support these investigations, palygorskite-rich clays from several locations were investigated. Palygorskite from Springbok Flats (Transvaal, RSA; cf. Heystek and Schmidt 1953) formed in a continental environment by weathering of basalt (transformation of montmorillonite to palygorskite). Phase diagram calculations of a palygorskite-rich sample P SF (Fig. 3, Fig. S3, Table S4) reveal a wide whiteschist stability field ranging from 560 to $760{ }^{\circ} \mathrm{C}$ at 0.7-3.9 GPa. Aside from talc, kyanite, and a $\mathrm{SiO}_{2}$ phase, the whiteschist mineral assemblages include lawsonite, chlorite, chloritoid, Ca-amphibole, orthopyroxene, and garnet. Palygorskite from Yucatán (Mexico) developed in a tranquil marine back-reef lagoon. There, palygorskite formed diagenetically when montmorillonite reacted with dolomitic limestone and silicic acid (de Pablo-Galán 1996). Compared to the palygorskite from Springbok Flats, the sample P Yu from Yucatán reveals a somewhat smaller stability field for whiteschist mineral assemblages ranging from 600 to $740{ }^{\circ} \mathrm{C}$ at $0.75-3.8 \mathrm{GPa}$ (Fig. S4, Table S5). This smaller stability field is the result of the higher chemical variability of the Yucatán palygorskite with higher contents of $\mathrm{Ca}, \mathrm{K}$, and $\mathrm{Na}$. The whiteschist mineral assemblages include white micas, biotite, omphacite, and glaucophane, but lack chloritoid and lawsonite. A similar stability field is obtained for palygorskite sample P Ip from Ipswich in Queensland (Australia; Rogers et al. 1954), which formed in Tertiary fresh water beds due to tropical weathering of basalt to sepiolite and subsequent addition of $\mathrm{Al}$ in the soil (cf. Fig. S5 and Table S6).

\section{Sepiolite-bearing pelites}

Another Mg-rich clay mineral of interest for the formation of whiteschist is sepiolite, which has the formula $\mathrm{Mg}_{4} \mathrm{Si}_{6} \mathrm{O}_{15}(\mathrm{OH})_{2} * 6 \mathrm{H}_{2} \mathrm{O}$ and may form a solid solution with palygorskite (García-Romero and Suárez 2010). Sepiolite often occurs together with palygorskite in lacustrine sediments, evaporites, eolian sediments, clay deposits near ultramafic bedrocks, epicontinental marine environment [for a review see (Jones and Conko 2011)], hydrothermally altered volcanics (Irkec and Ünlü 1993), and veins (Post 1978; Yeniyol 1986). Due to the absence of aluminum, no whiteschist mineral assemblages may form by the metamorphic overprint of pure sepiolite. However, the presence of other clay minerals may render this material a suitable protolith for whiteschists. Figure S6 shows a phase diagram for a 70:30 mixture of sepiolite (analysis of
Post 1978) and residual clay mainly made up of kaolinite and quartz (analysis of Isphording 1984) with a whiteschist stability field ranging from 600 to $750{ }^{\circ} \mathrm{C}$ at $0.75-3.75 \mathrm{GPa}$ (see also Fig. S6 and Table S7). Whiteschist mineral assemblages yield talc, kyanite, a $\mathrm{SiO}_{2}$ phase, garnet, orthopyroxene, omphacite, glaucophane, hornblende, paragonite, chlorite, and feldspar.

Rocks with sepiolite and other clay minerals are found in the Calatayud-Teruel Basin in northeastern Spain. These sediments were formed in a semi-arid, warm climate of the Tertiary in an alkaline, continental lacustrine environment (Torres-Ruiz' et al. 1994). Phase diagram calculation of numerous sepiolite-bearing pelites from this basin show whiteschist mineral assemblages. Figure 4 shows the phase diagram for pelite sample CALA4 from Torres-Ruiz' et al. (1994), which mainly consists of sepiolite, illite, and quartz (see also Fig. S7 and Table S8). The whiteschist stability field ranges from 600 to $760{ }^{\circ} \mathrm{C}$ at $0.75-3.2 \mathrm{GPa}$ and yields mineral assemblages with talc, kyanite, coesite or quartz, garnet, orthopyroxene, hornblende, lawsonite, white mica, biotite, chlorite, lawsonite, hornblende, and chloritoid. The same applies to samples consisting of sepiolite, palygorskite, illite, and smectite from the Tajo Basin and the Duero Basin (Torres-Ruiz' et al. 1994), which also form part of the Spanish Tertiary lacustrine basins.

\section{Pelites from evaporite successions}

Pelites associated with or sedimented during evaporitic cycles are of special interest. These rocks often bear considerable modal amounts of sepiolite and palygorskite (for a review see Jones and Conko 2011) but may also contain prominent amounts of chlorite, illite, smectite or mixedlayer clay minerals like corrensite (Moine et al. 1981). Clays from evaporite-bearing successions yield high concentrations of magnesium and large amounts of aluminum; that is why, Kulke and Schreyer (1973), Schreyer (1977), and Moine et al. (1981) assigned an evaporitic origin to whiteschists. Moine et al. (1981) investigated clays from the Aquitaine Basin (France) and the Canning Basin (Australia) and several of these rocks proved to be potential protoliths for whiteschists. For instance, sample 667418 is an argillite consisting of $95 \% \mathrm{Mg}$-chlorite and $5 \%$ illite, which originates from a Triassic shallow marine sequence of the Aquitaine Basin (Moine et al. 1981). Phase diagram calculations display a whiteschist stability field ranging from 600 to $730{ }^{\circ} \mathrm{C}$ at $0.73-3.3 \mathrm{GPa}$ (Fig. 5, Fig. S8, Table S9). Mineral assemblages include talc, kyanite, a $\mathrm{SiO}_{2}$ phase, garnet, orthopyroxene, omphacite, hornblende, lawsonite, white mica, and biotite. 
Metasomatic rocks, hydrothermal veins, and metamorphic segregates

Pervasive metasomatism can distinctly modify sedimentary, magmatic, and metamorphic rocks by removing $\mathrm{Ca}$ and alkali elements and adding $\mathrm{Mg}$ and $\mathrm{Al}$. Metasomatism may be related to tectonometamorphic events, interaction of hot seawater with the seafloor and infiltration of magmatic hydrothermal fluids.

\section{Metasomatic gneisses from the Rabenwald talc deposit (Austria)}

The Rabenwald deposit is located $120 \mathrm{~km}$ southwest of Vienna and consists of polymetamorphic Paleozoic orthoand paragneisses, which experienced metasomatism during intense Alpine tectonic overprint (Moreau 1981). Fluid inclusion studies reveal P-T conditions of $500-550{ }^{\circ} \mathrm{C}$ at 0.8-0.9 GPa for the metasomatism (asterisk in Fig. 6), which produced a large-scale migration of $\mathrm{Mg}$ and leaching of alkalies, Ca, Sr, and Ba (Moine et al. 1989).

In the zones of the strongest overprint, the metasomatic orthogneisses (zones A and B of Moine et al. 1989), the talc-chlorite ore and the metasomatic paragneisses yield whiteschist mineral assemblages in the calculated phase diagrams. Figure 6 shows the phase diagram of sample $12 \mathrm{~d}$, a metasomatic paragneiss containing the assemblage quartz-kyanite-chlorite (Moine et al. 1989; see also Fig. S9 and Table S10). The stability field for whiteschist shows a wide extension from 540 to $760{ }^{\circ} \mathrm{C}$ at $0.7-4.0 \mathrm{GPa}$. In addition to talc and kyanite, whiteschist mineral assemblages always include a $\mathrm{SiO}_{2}$ phase (alpha-quartz or coesite), chlorite at low temperature, chloritoid and garnet at high pressure, and orthopyroxene at high temperature. Remarkable is the enormous modal amount of talc and kyanite (up to $\sim 83$ vol.\%; see Table 2 ) generated in this rock during whiteschist metamorphism.

Figure S10 displays the phase diagram of sample 42a, a metasomatic orthogneiss (cf. Moine et al. 1989), which contains the mineral assemblage quartz-phengite-chlorite. The stability field for whiteschist assemblages ranges from 550 to $740{ }^{\circ} \mathrm{C}$ at $1.0-3.9 \mathrm{GPa}$. Similarly to the paragneiss from the same location, whiteschist mineral assemblages contain chlorite, garnet, chloritoid, orthopyroxene and furthermore biotite, white micas, glaucophane, jadeite, as well as kyanite, talc, and a $\mathrm{SiO}_{2}$ phase (Fig. S10, Table S11).

Note, if the Alpine metasomatism had occurred at higher temperatures and slightly higher pressure, the rocks of the Rabenwald deposit would not be quartz-chlorite schists with variable amounts of kyanite or phengite, but would be whiteschists (Fig. 6 and S10). The Rabenwald examples demonstrate that whiteschist formation does not require poly-stage processes if metasomatism occurs at sufficiently high $\mathrm{P}$ and $\mathrm{T}$ conditions.

\section{Metasomatic rocks from the Trimouns deposit (France)}

The Trimouns talc and chlorite deposit is located south of Toulouse in the north Pyrenean zone in southern France. At its footwall, crystalline schists, migmatites, and gneisses are found. They are overthrusted by a sequence of epimetamorphic schists with thick dolomite layers (Zwart 1953; Guchereau 1975). Post-tectonic Variscan metasomatism occurred at $\sim 400{ }^{\circ} \mathrm{C}$ and $0.1 \mathrm{GPa}$. Similar to Rabenwald, metasomatism resulted in a distinct addition of $\mathrm{Mg}$ and $\mathrm{H}_{2} \mathrm{O}$, a leaching of alkali elements, $\mathrm{Ca}, \mathrm{Sr}$, and $\mathrm{Ba}$ as well as a partial leaching of $\mathrm{Si}$. The elements $\mathrm{Al}, \mathrm{Fe}, \mathrm{Ni}$, $\mathrm{V}$, and Ti behaved relatively immobile (Moine et al. 1989).

Metasomatic schists, gneisses as well as the talc ore and the chlorite ore in the zones of most intensive metasomatism (zones A, B and C of Moine et al. 1989) yield whiteschist mineral assemblages in the calculated phase diagrams. Compared to the metasomatic rocks from Rabenstein, the Trimouns samples are somewhat depleted in silica. This is well visible from the phase diagram of sample Lc16b (Moine et al. 1989), a metasomatic quartzchlorite schist (Fig. 7, Fig. S11, Table S12). The stability field for whiteschist assemblages ranges from 520 to $760{ }^{\circ} \mathrm{C}$ at $0.65-4.0 \mathrm{GPa}$. Quartz- or coesite-bearing whiteschist assemblages only appear at the high- and the low-temperature limit of the stability field, whereas the central part of this field consists of assemblages free of these minerals. Additional silicate minerals are chlorite, white mica, chloritoid at low temperatures, orthopyroxene at high temperatures, and garnet at high temperatures and pressures. Similar to sample $12 \mathrm{~d}$ from the Rabenwald deposit, sample Lc16b yields tremendous modal amounts of talc and kyanite (up to 85.5 vol.\%, cf. Table 2). Figure S12 shows the phase diagram for sample 16d (Moine et al. 1989), a chlorite ore from metasomatic zone A (see also Table S13). The stability field for whiteschist assemblages extends from 540 to $730{ }^{\circ} \mathrm{C}$ at $0.75-2.75 \mathrm{GPa}$. There is virtually no $\mathrm{SiO}_{2}$ phase in the diagram, which displays mineral assemblages with kyanite, talc and additionally lawsonite and chlorite, Ca-amphibole, biotite, garnet, and orthopyroxene.

\section{Metasomatically altered volcanic rocks from Kristineberg (Sweden)}

Early Proterozoic volcanic rocks of the Kristineberg area host numerous volcanogenic massive sulfide (VMS) deposits (e.g., Allen et al. 1996). The volcanic rocks experienced a polyphase overprint beginning with a spilitization at the seafloor (Vivallo and Willdén 1988) 
followed by a VMS-related quartz-sericite to quartz-chlorite hydrothermal alteration. This hydrothermal alteration went along with intense magnesium and fluorine metasomatism and leaching of potassium (Hannington et al. 2003). Furthermore, iron was nearly completely bound to disseminated pyrite (Richards et al. 1989). Later, the rocks were overprinted by regional metamorphism at upper greenschist to lower amphibolite facies.

Phase diagram calculations of hydrothermally altered metavolcanics from the Kristineberg area [analyses taken from Hannington et al. (2003)] including cordierite-biotite schists, quartz-muscovite schists, and chlorite schists yield stability fields of whiteschist mineral assemblages. Figure 8 shows the phase diagram of metavolcanic chlorite schist sample 72202-21.2, which had experienced a hydrothermal overprint prior to metamorphism. The whiteschist stability field ranges from 610 to $710{ }^{\circ} \mathrm{C}$ at 0.8-3.2 GPa. Aside from talc, kyanite, and quartz or coesite, mineral assemblages include garnet, orthopyroxene, white mica, and biotite (Fig. 8, Fig. S13, Table S14).

\section{Sepiolite-bearing, hydrothermally altered volcanic rocks from Kibriscik (Turkey)}

The Köroglu volcanic belt is located northwest of Ankara (Turkey) and consists of Miocene basaltic and andesitic lava flows and vitric tuff layers of dacitic to rhyolitic composition that in part show strong hydrothermal argillitic alteration (Irkec and Ünlü 1993). Most of the altered samples of Irkec and Ünlü (1993) contain large modal amounts of Al- and Fe-bearing sepiolite as well as minor amounts of montmorillonite, zeolite, feldspar, quartz, cristobalite, and amorphous silica. Most of these samples are possible protoliths for whiteschists. Sample KIB-6B, for example, originates from a layer consisting of abundant Al-sepiolite and minor zeolite. Phase diagram calculations indicate a stability field for whiteschist mineral assemblages at $600-725^{\circ} \mathrm{C}$ and $0.8-3.6 \mathrm{GPa}$ (Fig. S14, Table $\mathrm{S} 15)$. The mineral assemblages strongly resemble the ones recorded in the argillitically altered metavolcanic sample 72202-21.2 from Kristineberg but additionally yield chloritoid at high and ultrahigh pressures as well as hornblende and chlorite at intermediate to high pressures.

\section{Hydrothermal palygorskite veins in mafic volcanics from the central California margin fracture zone (USA)}

Hydrothermal occurrences of palygorskite are widely known. For instance, Stephen (1954) found hydrothermal palygorskite on the Shetland Isles, Christ et al. (1969) investigated hydrothermal palygorskite and calcite in hydrothermal veins from New Mexico (USA), and Furbish and Sandow (1976) described direct precipitation of palygorskite in fractures of the Day Book dunite (North Carolina, USA). Gibbs et al. (1993) describes hydrothermal palygorskite-associated with ferromanganese mineralization-that formed due to interaction of hydrothermal fluids with oceanic basalt and/or ultramafic rocks in boxworktextured veins and by direct precipitation in mudstone at the seafloor. Phase diagram calculations for sample D8-9B from Gibbs et al. (1993), which consists of pure palygorskite blades from a hydrothermal vein, yield a whiteschist stability field ranging from 610 to $760{ }^{\circ} \mathrm{C}$ at 0.75-3.4 GPa (Fig. 9, Fig. S15, Table S16). Mineral assemblages include talc, kyanite, quartz or coesite and additionally garnet, orthopyroxene, glaucophane, white micas, and biotite. Remarkable features of the phase diagram are two small triangular sections within the whiteschist stability field, which are devoid of kyanite.

\section{Metasomatic mafic and ultramafic rocks}

Metasomatic ultramafic rocks from Blackwall zones, that is, contact zones between serpentinites and granitoid or gneissic wall rocks, often yield elevated contents of $\mathrm{Mg}$ and $\mathrm{Al}$ and therefore might be potential protoliths of whiteschists. However, phase diagram calculations of chloritites from the Habachtal and from the Greiner shear zone in the Tauern Window of the Eastern Alps (see Okrusch et al. 1981; Barnes et al. 2004) show that these rocks contain far too little $\mathrm{SiO}_{2}$ and therefore generate the mineral assemblage olivine + spinel instead of talc + kyanite at the appropriate P-T conditions (see Fig. S16 and Table S17). Only the addition of considerable amounts of quartz (e.g., a mixture of $75 \%$ chloritite and $25 \%$ quartz) would lead to an extended whiteschist stability field (see Fig. S17 and Table S18). The lack of quartz in Blackwall zones, however, prevents the formation of whiteschists. For the same reason, Ca-poor rodingites and rocks from rodingite-serpentinite contact zones (e.g., Schandl et al. 1989) are unsuitable to produce whiteschists.

\section{Eclogite-facies quartz veins from the Dabie Shan (China)}

High-pressure quartz veins are located within retrograde eclogites (Franz et al. 2001) of the high- and ultrahighpressure metamorphic Dabie Shan mountain belt. These veins, which incorporate talc, kyanite, garnet, omphacite, Ca-amphibole, rutile and in some sections clinozoisite and carbonate, formed by extensive hydraulic fracturing during eclogitization. The fluid responsible for the mineralization probably originated from syn-metamorphic dehydration processes of crustal rocks. $\mathrm{P}-\mathrm{T}$ conditions for the formation of the vein were determined with the TWQ program (Berman 1991) at $\sim 590{ }^{\circ} \mathrm{C}$ and $1.95 \mathrm{GPa}$ (Franz et al. 2001). The composition of the vein section modeled with 
the THERIAK/DOMINO program was determined by point counting of a talc and kyanite-rich thin section. The phase diagram of sample HPV2 (Fig. 10, Fig. S18, Table S19) displays a wide stability field for whiteschist ranging from 560 to $720{ }^{\circ} \mathrm{C}$ at $0.7-3.7 \mathrm{GPa}$. The stability field for the mineral assemblage Grt-Omp-Hbl-Tc-Ky-Qtz is at somewhat higher pressures and temperatures $\left(600-710{ }^{\circ} \mathrm{C}\right.$ at 2.2-2.5 GPa) than the TWQ calculation (see asterisk in Fig. 10) although still within the uncertainty of the methods. Whiteschist mineral assemblages include lawsonite, chloritoid, and paragonite at low temperatures, garnet, glaucophane, and omphacite at high pressures and intermediate temperatures and orthopyroxene, Ca-amphibole, and plagioclase at elevated temperatures and intermediate pressures. All assemblages include kyanite, talc and quartz, or coesite.

\section{Chemical controls of whiteschist formation}

\section{Effect of $\mathrm{CO}_{2}$}

As outlined above, most of the investigated sedimentary environments for potential whiteschist protoliths are shallow marine or lacustrine. Therefore, the protoliths may contain considerable amounts of carbonate. As metasomatic, hydrothermal, and metamorphic rocks also may contain carbonates, the effect of $\mathrm{CO}_{2}$ on the phase diagram will be evaluated. As carbonates are particularly abundant in evaporites, we chose clay sample 667418 of Moine et al. 1981; see Fig. 5 for the phase diagram modeling. Figure 11, a plot of temperature versus $\mathrm{CO}_{2}$-activity $\left(\mathrm{a}\left(\mathrm{CO}_{2}\right)\right)$ at a pressure of $2.5 \mathrm{GPa}$, explicitly shows the limitation of the whiteschist stability field (see also Fig. S19 and Table S20). At a temperature of $640{ }^{\circ} \mathrm{C}$, for example, the mineral assemblage garnet-white micaomphacite-hornblende-kyanite-talc-quartz is stable at an $\mathrm{a}\left(\mathrm{CO}_{2}\right)$ of $0-<0.036$, whereas at $\mathrm{a}\left(\mathrm{CO}_{2}\right)$ values of 0.036-0.064 magnesite is formed at the expense of talc and hornblende. At a $\left(\mathrm{CO}_{2}\right)$ values of $>0.064-0.92$, dolomite joins the assemblage and at $\mathrm{a}\left(\mathrm{CO}_{2}\right)>0.92$ additional feldspar appears. This diagram shows that even small concentrations of $\mathrm{CO}_{2}$ in the metamorphic fluid drastically reduce the stability of whiteschist mineral assemblages.

\section{Effect of $\mathrm{H}_{2} \mathrm{O}$}

The water activity of metamorphic fluids is strongly dependent on coexisting volatile phases like $\mathrm{CO}_{2}, \mathrm{CH}_{4}$, and $\mathrm{N}_{2}$ but also on solvents (e.g., salt) in the aqueous solution (e.g., Aranovich and Newton 1999; Shmulovich and Graham 2004; Frezzotti et al. 2007). Especially at high to ultrahigh pressure, the activity of $\mathrm{H}_{2} \mathrm{O}$ is often reduced (e.g., Chopin and Monié 1984; Sharp et al. 1993). The effect of the water activity on the stability of whiteschist mineral assemblages is shown for clay sample 667418 (Fig. 5) in a plot of temperature versus $\mathrm{a}\left(\mathrm{H}_{2} \mathrm{O}\right)$ at a pressure of $2.5 \mathrm{GPa}$ (Fig. 12, Fig. S20, Table S21). Decreased water activity distinctly limits the stability of the whiteschist mineral assemblages at high temperature. At $700^{\circ} \mathrm{C}$, for example, the assemblage garnet-white mica-hornblendekyanite-talc-quartz is only stable at an $\mathrm{a}\left(\mathrm{H}_{2} \mathrm{O}\right)$ near 1.0 , and with decreasing water activity, kyanite and eventually talc are decomposed. On the other hand, decreasing a $\left(\mathrm{H}_{2} \mathrm{O}\right)$ stabilizes the whiteschist assemblage at lower temperatures, for example, at $500{ }^{\circ} \mathrm{C}$, the assemblages garnet-white mica-omphacite-hornblende-kyanite-talc-quartz and garnet-white mica-omphacite-kyanite-talc-quartz are stable at $\mathrm{a}\left(\mathrm{H}_{2} \mathrm{O}\right)$ values of $0.15-0.47$. At higher temperatures, talc is decomposed at lower and kyanite disappears at higher water activities. Chopin and Monié (1984) measured an $\mathrm{a}\left(\mathrm{H}_{2} \mathrm{O}\right)$ of 0.6 for the magnesian HP-metapelites in the Furgg Unit of the Monte Rosa nappe, and Le Bayon et al. (2006) concluded from phase diagram calculations on whiteschists from the Monte Rosa nappe that the observed mineral assemblages are stable at an $\mathrm{a}\left(\mathrm{H}_{2} \mathrm{O}\right)$ between 0.59 and 0.66. Similar observations have been made by Sharp et al. (1993). We therefore assumed a water activity of 0.6 and calculated an equilibrium phase diagram for sample 667418 (Fig. S21, Table S22). The mineral assemblages and the modal mineral amount in the central part of the largest whiteschist stability field correspond to those displayed in Fig. 5, that is, the calculation for the same sample at $\mathrm{a}\left(\mathrm{H}_{2} \mathrm{O}\right)=1$. However, the whiteschist stability field at $\mathrm{a}\left(\mathrm{H}_{2} \mathrm{O}\right)=0.6$ is distinctly shifted toward lower temperatures and obviously expanded to temperatures and pressures ranging from 540 to $650{ }^{\circ} \mathrm{C}$ at $0.6-3.7 \mathrm{GPa}$, respectively (Fig. S21).

\section{Effect of oxygen fugacity}

Schreyer (1974) noted that the bulk composition of whiteschist protoliths must have low $\mathrm{Ca}$ and alkali contents, high $\mathrm{Mg}$ contents and, if iron is present, a high ferric/ ferrous ratio. The presence of yoderite $\left(\mathrm{Mg}_{2} \mathrm{Al}_{5.6} \mathrm{Fe}_{0.4}^{3+-}\right.$ $\mathrm{Si}_{4} \mathrm{H}_{2} \mathrm{O}_{20}$; see Fockenberg and Schreyer 1994) and hematite as well as piemontite and manganian andalusite in the whiteschists of Mautia Hill, Tanzania (McKie 1959; Jöns and Schenk 2004) indicate that these whiteschists experienced elevated oxygen fugacities. Highly oxidizing conditions were also recorded by the yoderite-bearing Kadunguri whiteschists of the Zambezi belt in northern Zimbabwe (Johnson and Oliver 2002). In both African whiteschist occurrences, the percolation of a syn-metamorphic, high- $\mathrm{fO}_{2}$ metasomatic fluid was postulated (Johnson and Oliver 2002; Jöns and Schenk 2004). The 
main effect of high $\mathrm{fO}_{2}$ is the fixation of ferrous iron in oxide minerals and subordinately in silicates, which also may apply to manganese. Phase diagram calculations with increased oxygen fugacity were performed for several samples to highlight the effect of oxygen fugacity on the topology. Figure S22 shows the whiteschist stability field for the metasomatic paragneiss sample $12 \mathrm{~d}$ from Rabenwald calculated with an oxygen fugacity fixed at the magnetite-hematite buffer (see also Table S23). The extent of the whiteschist stability field, its mineral assemblages, and the modal mineral amount are almost identical to those calculated without elevated $\mathrm{fO}_{2}$ (cf. Fig. 6; Table 2) with the exception of a segment at $P<1.05 \mathrm{GPa}$, where yoderite joins the assemblage talc-kyanite-quartz at the expense of chlorite or orthopyroxene, respectively. Figure 13 shows a phase diagram for the same sample calculated with oxygen in excess. The stability field is distinctly extended ranging from 515 to $780{ }^{\circ} \mathrm{C}$ at 0.6-4.1 GPa. The ultrahigh-pressure assemblage is made up of talc-kyanite-coesite-hematite, while at intermediate to high pressures, talc-kyanite-quartz-hematite is observed. At pressures $<1.05 \mathrm{GPa}$, the assemblage talc-kyaniteyoderite-quartz-hematite is stable. Remarkable is the wide extension of the yoderite stability field toward lower temperatures and pressures (Fig. 13, Fig. S23, Table S24).

Figure S24 shows a phase diagram for the Mg-rich metapelite sample BEHR-97-100 calculated with an oxygen fugacity at the magnetite-hematite buffer (see also Table S25). While the whiteschist stability field and the mineral assemblages are identical to those in Fig. 1 (i.e., the calculation without elevated $\mathrm{fO}_{2}$ ), yoderite-bearing assemblage form at temperature around $600{ }^{\circ} \mathrm{C}$ and pressures of $0.5-0.7 \mathrm{GPa}$. A calculation for the same sample with $\mathrm{O}$ in excess reveals an even wider stability field for whiteschist and yoderite. The whiteschist stability field ranges from 510 to $760{ }^{\circ} \mathrm{C}$ at $1.0-4.0 \mathrm{GPa}$ (Fig. 14) and the modal amount of talc and kyanite distinctly increases (Table 2). Although the stability field for yoderite-bearing assemblages is distinctly extended by higher oxygen fugacity, yoderite may coexist with talc, but not with both talc and kyanite in sample BEHR-97-100 (Fig. 14, Fig. S25, Table S26).

Elevated $\mathrm{fO}_{2}$ during metamorphism at eclogite-facies conditions can even transform pelites with high concentrations of calcium and alkalies to whiteschists (Figs. S26 and S27). Sample 800 is a pelitic turbidite with volcanogenic components from the ocean floor near the Marianas. Phase diagram calculations without elevated $\mathrm{fO}_{2}$ reveal metapelitic mineral assemblages including garnet, micas, chlorite, orthopyroxene, glaucophane, omphacite, lawsonite, coesite or quartz, hornblende, feldspar, and talc, whereas kyanite is absent (cf. Fig. S26, Table S27). The calculation of the same diagram with $\mathrm{O}$ in excess reveals a whiteschist stability field at elevated pressures ranging from 560 to $760{ }^{\circ} \mathrm{C}$ at 2.3-4.0 GPa (Fig. S27, Table S28). Whiteschist assemblages include large amounts of talc and kyanite ( $>22 \mathrm{wt} \%$; see Table 2) along with white micas, omphacite, lawsonite, hornblende, coesite or quartz, and hematite.

\section{Effect of sulfur}

Similar to elevated oxygen fugacities, the presence of sulfur may also extract iron from the system taking part in mineral reactions by fixing it to phases like pyrite and pyrrhotite. This may be the case in sulfur-rich evaporitic sediments and especially in black shales. Due to the lack of thermodynamic data for high- and ultrahigh-pressure modifications of these sulfides, a calculation of phase diagrams is not possible. Qualitatively, the following scenarios can be envisaged: (1) Sulfur in evaporates occurs as Ca-sulfate or native sulfur. If Ca-sulfate was inert during diagenesis and prograde metamorphism, there would be no effects on the mineral assemblage. In case of a Ca-sulfate reduction, $\mathrm{S}$ could bind $\mathrm{Fe}$, but the release of $\mathrm{Ca}$ would stabilize amphibole, feldspar, pyroxene, or garnet, removing $\mathrm{Al}$ and/or $\mathrm{Mg}$ from the system, and thus preventing the formation of whiteschist mineral assemblages. Native sulfur triggers reducing conditions in the rock sequence and binds $\mathrm{Fe}$ in sulfide minerals. The increasing $\mathrm{X}_{\mathrm{Mg}}$ then would favor the formation of whiteschist assemblages in pelitic evaporites. (2) Sulfur in organic-rich pelites (e.g., black shales) may act in a similar way like native sulfur in evaporitic pelites. Heavy metal elements like $\mathrm{Fe}, \mathrm{Cu}, \mathrm{Pb}$, and $\mathrm{Zn}$ in the sediment and from percolating fluids could be bound in sulfide minerals, thus increasing $X_{M g}$ and stabilizing whiteschist mineral assemblages.

\section{Discussion}

As pointed out by several studies, whiteschists require a very special protolith composition and a metamorphic overprint under high- and ultrahigh-pressure eclogite-facies conditions (e.g., Schreyer 1973, 1974, 1977; Kulke and Schreyer 1973; Chopin and Monié 1984; Johnson and Oliver 2002; Rolfo et al. 2000; Pawling and Baumgartner 2001; Hermann 2003; Groppo et al. 2007), which exclusively occurs in subduction zones. Our phase diagram calculations reveal a wide stability field for whiteschist mineral assemblages from amphibolite facies conditions at $0.5 \mathrm{GPa}$ and $550{ }^{\circ} \mathrm{C}$ to ultrahigh-pressure eclogite-facies conditions at $>4 \mathrm{GPa}$ and $770{ }^{\circ} \mathrm{C}$. The size and shape of the stability field strongly depend on the rock composition.

Numerous investigations show that the primary protolith for whiteschists must be a MFASH rock with small 
amounts of alkalies, calcium and iron (e.g., Schreyer 1973, 1974, 1977; Kulke and Schreyer 1973; Chopin and Monié 1984; Johnson and Oliver 2002; Wei and Powell 2003; Ferrando 2012). For high alkali-element contents, mica is formed instead of kyanite, whereas high calcium contents tend to stabilize Ca-amphibole and clinopyroxene instead of talc. Elevated contents of calcium and sodium stabilize plagioclase at lower pressures and omphacite-rich clinopyroxene at higher pressures. Large amounts of ferrous iron lead to the growth of chloritoid at low and orthopyroxene at high temperatures, while almandine-rich garnet forms at medium and high pressures. Similar observations have been presented by Wei and Powell (2003) who performed equilibrium phase diagram calculations in the KFMASH, KMASH and KFASH system. Our calculations demonstrate that an extended whiteschist stability field is only possible with protoliths showing the following geochemical constraints: $\mathrm{X}_{\mathrm{Mg}}\left(=\mathrm{Mg} / \mathrm{Mg}+\mathrm{Fe}^{2+}\right)$ should be $>0.77(\mathrm{Al}+\mathrm{Mg}) /\left(\mathrm{Fe}^{2+}+\mathrm{Ca}+\mathrm{K}+\mathrm{Na}\right)$ should be $>2.4$ and $(\mathrm{Al}+\mathrm{Si}) /\left(\mathrm{Fe}^{2+}+\mathrm{Ca}+\mathrm{K}+\mathrm{Na}\right)$ should be $>8$ (see Table 1; all values are mole proportions). Such rocks are very rare in nature and therefore, metasomatic alteration with removal of the alkalies, calcium, and iron has been inferred for many natural occurrences (e.g., Schreyer 1973, 1974, 1977; Kulke and Schreyer 1973; Chopin and Monié 1984; Johnson and Oliver 2002; Ferrando et al. 2009; Ferrando 2012). An AFM plot for the K-bearing samples (Fig. S29a) clearly shows the influence of the $\mathrm{X}_{\mathrm{Mg}}$ on whiteschist mineral assemblages. Rocks with extended whiteschist stability fields are very Mg-rich (see broken line), which is in accordance with AFM compatibility diagrams of Wei and Powell (2003). An $\mathrm{Al}_{2} \mathrm{O}_{3}-\mathrm{SiO}_{2}$ $(\mathrm{FeO}+\mathrm{MgO}$ ) plot for all samples (Fig. S29b) shows that only rocks with elevated amounts of $\mathrm{SiO}_{2}$ are able to generate whiteschist mineral assemblages (cf. broken line). The plot furthermore outlines the importance of the $X_{\mathrm{Mg}}$ value for the formation of the whiteschists as pelites with a very small or without any whiteschist stability field plot among the samples with prominent whiteschist mineral assemblages.

An important effect on the chemical composition of the whiteschists is the growth of the garnet. Prograde garnet growth may sequester $\mathrm{Fe}$ from the bulk rock, which is observed for the Dora-Maira whiteschists (e.g., Ferrando et al. 2009). Such a compositional zoning in garnet may even lead to whiteschist mineral assemblages in rocks with lower $\mathrm{X}_{\mathrm{Mg}}$ values.

Many models for the formation of whiteschists postulate extensive metasomatism of the protolith before or during prograde high-pressure metamorphism (e.g., Munz 1990; Johnson and Oliver 2002; Rolfo et al. 2000; Pawling and Baumgartner 2001), or even at the peak of the ultrahighpressure metamorphism (Compagnoni and Hirajima 2001;
Ferrando et al. 2009; Ferrando 2012). Such Mg-metasomatism is often triggered by channelized fluids derived from associated serpentinites (for a review of Mg-metasomatism in Alpine metagranitoids see Ferrando 2012).

Earlier investigations also showed that metasomatism must preferably occur at high oxygen fugacity to fix iron in oxides like magnetite, hematite, or $\mathrm{Fe}^{3+}$-bearing silicates like yoderite (e.g., McKie 1959; Schreyer 1977; Fockenberg and Schreyer 1994). The presence of hematite and elevated amounts of $\mathrm{Mn}^{3+}$ in silicates of the Mautia Hill whiteschists indicate a very high oxygen fugacity (Jöns and Schenk 2004), which is also true for the yoderite-whiteschists intercalated with quartz-hematite bands from the Zambezi belt (Johnson and Oliver 2002). As an exact determination of the oxygen fugacity during these metasomatic processes is not possible, we calculated phase diagrams both at the magnetite-hematite buffer and with oxygen in abundance to cover a wide range of conditions. While calculations at the magnetite-hematite buffer had little effect on the whiteschist stability field, calculations with oxygen in abundance show that even pelites with relatively high contents of iron may generate whiteschist mineral assemblages with elevated modal amounts of talc and kyanite under HP- to UHP-metamorphic conditions (cf. Figs. S22-27 and Table 2). High sulfur contents trigger reducing conditions in the host rock and may have a similar effect on Fe-rich rocks as high oxygen fugacities, that is, stabilization of whiteschist mineral assemblages due to iron fixation in sulfides.

Remarkable effects are recorded for whiteschists metamorphosed under lower water fugacity: the whiteschist stability field is distinctly expanded and shifted toward lower temperatures (cf. Fig. 5 and S21).

The formation of whiteschists is strongly limited by the influence of $\mathrm{CO}_{2}$, which drastically reduces the stability field of whiteschist by the growth of magnesite instead of talc (cf. Figs. 5, 11). This is of special importance for protoliths from evaporitic successions, which may have important contributions of Mg-carbonates (e.g., Galán and Pozo 2011; Jones and Conko 2011) but also excludes the formation of whiteschists in presence of a metasomatic $\mathrm{CO}_{2}$-rich fluid phase.

Our studies indicate that numerous rock types may be the protoliths for whiteschists. We could demonstrate that metasomatically overprinted magmatic and sedimentary rocks may generate whiteschist mineral assemblages; metasomatic metasedimentary rocks like quartz-chlorite schists and quartz-kyanite-chlorite schists as well as argillitically altered granitoids and tuff are transformed to whiteschists at moderate to ultrahigh pressures and intermediate to high temperatures (Figs. 6, 7, 8, S10, S12, S14). These rocks, however, are usually rare and often restricted to very special tectonometamorphic settings, as for 
instance, contact metamorphic alterations around shallow granites at active continental margins (e.g., alterations associated with porphyry copper mineralizations). Similarly to the metasomatic rocks, rare metamorphic segregates, which formed during HP-metamorphism, bear whiteschist mineral assemblages under ultrahigh- to medium-pressure conditions at intermediate to high temperatures (Fig. 10). Experimental work has shown that Mgcarpholite decomposes to the assemblage talc + kyanite + chlorite + vapor at high temperatures and pressures and talc + kyanite + chloritoid + vapor at high temperatures and higher pressures, whereas $\mathrm{Mg}$-carpholite + quartz decomposes at slightly lower temperatures to the assemblage talc + kyanite (Chopin and Schreyer 1983; system not modeled here), which implies that metamorphism of $\mathrm{Mg}$-carpholite and $\mathrm{Mg}$-carpholite + quartz veins, as known from, for example, western Turkey (e.g., Rimmelé et al. 2003), in the Alps (e.g., Goffé and Chopin 1986) or in the Apennines (e.g., Brogi and Giorgetti 2012), also would yield the whiteschist mineral assemblage when metamorphosed to higher grade. Similarly, the silvery micaschists from Gran Paradiso Massif (Meffan-Main et al. 2004), which mainly consist of talc, chlorite, and chloritoid, likely present low-temperature equivalents of whiteschists as demonstrated by Gabudianu Radulescu et al. (2009).

Pre- or syn-metamorphic metasomatism, however, is not an essential prerequisite for the formation of whiteschists. Phase diagram calculations show that palygorskite-rich pelitic rocks yield a wide stability field for whiteschist assemblages with high modal amounts of talc and kyanite (Table 2; Figs. 2, 3, and S4). These rocks usually form under tropical to subtropical conditions preferably in continental lacustrine or in shallow marine environments (e.g., Singer 1979; Callen 1984; Jones and Conko 2011). Palygorskite and Al-sepiolite may also form hydrothermally and occur in fractures or as monomineralic veins in mainly magmatic host rocks (Stephen 1954; Christ et al. 1969; Furbish and Sandow 1976; Gibbs et al. 1993). Furthermore, these minerals are found in discrete clay-rich layers of strongly hydrothermally overprinted volcanic rocks (Irkec and Ünlü 1993) providing a link to the metasomatically altered protoliths described before.

Although palygorskite-bearing clays can also be part of deep-sea sediments (Bonatti and Joensuu 1968; Couture 1977; Church and Velde 1979; Karpoff 1992; Karl et al. 1992), these rocks have too high iron, calcium, and alkalielement contents to be potential protoliths for whiteschists.

In contrast to the deep-sea clays, pelitic rocks from evaporitic successions made up of sepiolite, palygorskite and prominent amounts of chlorite, illite, smectite, or mixed-layer clay minerals like corrensite may well serve as precursors for whiteschists, which was already suggested by Kulke and Schreyer (1973), Schreyer (1977), and Moine et al. (1981). Evaporitic rocks are predominantly sedimented in hot and arid epicontinental marine settings and in Sabkha environments. Although these rocks commonly have appropriate $\mathrm{Mg}, \mathrm{Al}$, and Fe contents to form whiteschists, a significant portion of their $\mathrm{Mg}$ is bound in carbonates and they may have important $\mathrm{Ca}$ contents bound in carbonates and/or sulfates. Therefore, a closed-system metamorphism of evaporitic rocks typically does not produce whiteschist mineral assemblages. In open-system metamorphism with loss of $\mathrm{CO}_{2}$, however, whiteschist mineral assemblages may develop.

In most cases, average pelitic KFMASH rocks from marine environments are not suitable to form whiteschist, which is mainly due to their low contents of $\mathrm{Mg}$ and high contents of $\mathrm{Fe}$ and alkali elements. Mg-rich continental pelites, which experienced strong chemical weathering (loss of $\mathrm{Ca}$ and alkali elements), generally have too high $\mathrm{Fe}$ contents to produce whiteschist mineral assemblages. In rare cases, however, these rocks yield very limited whiteschist stability fields. However, pelitic rocks from marine and continental setting may show whiteschist mineral assemblages and an extended stability field for whiteschist mineral assemblages, respectively, if metamorphism occurs at very high oxygen fugacity (see above).

\section{Potential controls on size and distribution of whiteschist occurrences}

While metasomatically altered $\mathrm{Mg}$ - and Al-rich rocks are well suitable to be the protolith for whiteschists, their occurrence is rather limited to special tectonic settings or to rare rock sequences with thorough allochemical overprint. Although such metasomatic processes are observed in several locations, they are rare and do not explain the presence of numerous whiteschist occurrences in high- and ultrahigh-pressure rock suites. Palygorskite-bearing sediments as well as sediments containing (Al-)sepiolite, illite, and chlorite may well be suitable to be primary protoliths for whiteschists. Although clays of the palygorskite-sepiolite group may form in the open oceans by hydrothermal alteration of basaltic material, volcanic sediments, or clays (Callen 1984), these occurrences have a rather limited extent and typically contain calcium-, iron-, and manganese-rich material rendering them unsuitable as protoliths of whiteschists. The largest amount of the palygorskitesepiolite group minerals forms in epicontinental and inland seas and lakes as chemical sediments, and in calcareous soils by direct crystallization (Callen 1984; Jones and Conko 2011; Murray et al. 2011). These deposits often contain m-wide layers of pure clay minerals without additions of alkali elements, calcium or iron (e.g., Karl 
et al. 1992) and, therefore, are highly suited potential protoliths for whiteschists. Palygorskite- and sepiolite-rich clays generated in soils, lakes and shallow marine environment were mostly associated with a Mediterranean or warm, semi-arid climate, that is, in low latitudes (Moine et al. 1981). There is a distinct latitudinal distribution of palygorskite land deposits between 30 and $40^{\circ}$ in both hemispheres (Callen 1984). Palygorskite abundance on land seems to be more abundant in sedimentary rocks of the Cambrian, Devonian-Carboniferous, Permian-Triassic, Late Cretaceous to Eocene, Late Oligocene to Middle Miocene and Pliocene to Pleistocene (Callen 1984). Remarkably, there are times with a strong enrichment of $\mathrm{Mg}$ in seawater, that is, in Cambrian to Precambrian, in Carboniferous, Permian, Triassic, lower Jurassic and Neogene (Lowenstein et al. 2001; Warren 2010), which leads to the formation of $\mathrm{Mg}$-rich clays in evaporitic successions of that time (Warren 2010). Evaporites that formed in those times are potential protoliths for whiteschists. The occurrence and distribution of palygorskitesepiolite and $\mathrm{Mg}$-rich clays may represent a good indicator for palaeoclimatic and paleogeographic conditions (e.g., Singer 1979, 1980; Warren 2010). As sedimentary rocks with high contents of these minerals are protoliths for whiteschists, the paleogeographic setting, and the deposition age (i.e., palaeoclimate) of the sedimentary protoliths have an influence on whether whiteschists can be formed or not.

As demonstrated above, most of the protoliths for whiteschists originate from continental domains or from shallow marine (i.e., epicontinental or lagoonal) environments. However, such continental areas usually do not experience subduction with subsequent high-pressure/ low-temperature metamorphic overprint, which is the prerequisite for whiteschist formation. In settings of continental collision, however, continental crust is pushed to depths of high- and ultrahigh-pressure conditions and returns to crustal levels because of its lower density relative to the surrounding mantle (e.g., Ernst 2001; Roselle and Engi 2002; Chopin 2003; Brueckner 2006; Yamato et al. 2008). This relation between subduction of continental crust and high- to ultrahigh-pressure metamorphism explains the widespread and predominant occurrence of whiteschists in UHP-terranes. Only in rare cases, rocks of oceanic origin metamorphosed under UHP-conditions are found at the surface, for example, in the Lago di Cignana area of the Zermatt-Saas zone (Reinecke 1991, 1998; van der Klauw et al. 1997) in northern Italy. Remarkably, Mnrich, talc- and kyanite-bearing metapelites have been found in the Lago di Cignana area (Reinecke 1998), which have been interpreted as Mesozoic pelagic sediments covering an ophiolitic sequence (van der Klauw et al. 1997; see also Dal Piaz and Ernst 1978; Dal Piaz 1988). In contrast to this occurrence, whiteschists are absent in most other eclogitefacies successions from oceanic environments.

\section{Perspectives for future whiteschist research}

Significant syn-metamorphic material loss in the formation of whiteschists, as inferred in numerous earlier studies (e.g., Chopin et al. 1991; Sharp and Barnes 2004; John et al. 2004; Johnson et al. 2007; Ferrando et al. 2009; Ferrando 2012), changes the geochemical and isotopic signatures of the rock, either by loss of material or by introduction of material via the fluid that enables the bulk material loss. In either case, the geochemical and isotopic fingerprint of the protolith gets largely lost. For closed- and near-closed-system metamorphism, the geochemical and isotopic composition of the whiteschists may be used to constrain the protolith and its provenance. Our petrological modeling demonstrates that a wide range of different protoliths is suited to produce whiteschist mineral assemblages without any necessity for significant material loss. Actually, the whiteschist mineral assemblage may be obtained even for closed-system metamorphism. Thus, geochemical and isotopic data may allow distinguishing different whiteschist protoliths.

The various protoliths that yield whiteschist mineral assemblages have very different trace element contents and concentration ratios that may be used to distinguish between different protoliths. Especially suited are elements that are relatively immobile during metasomatism or weathering, as for instance, $\mathrm{Cr}$, Ti, or HFSEs. It should be noted that not only particularly high trace element contents or characteristic trace element ratios, but also exceptionally low trace element contents represent a geochemical fingerprint, especially if the considered elements are highly compatible in minerals present during the metamorphic development of the whiteschist mineral assemblage.

The radiogenic isotope systems $\mathrm{Rb}-\mathrm{Sr}, \mathrm{Sm}-\mathrm{Nd}, \mathrm{Lu}-\mathrm{Hf}$, and $\mathrm{U}-\mathrm{Th}-\mathrm{Pb}$ represent powerful tracers that provide constraints on the development of the protoliths. Tilton et al. (1989) used the isotopic composition of $\mathrm{Sr}, \mathrm{Nd}$, and $\mathrm{Pb}$ to demonstrate that the protolith of the Dora-Maira UHP rocks represents old continental crust, focusing on the point that continental crust may be subducted to mantle depth and that such material-when interacting with the mantle-may account for the enriched geochemical and isotopic signature of some mantle types. Their isotope data, however, provide also powerful constraints on the development of the protoliths. For instance, the $\mathrm{Nd}$ data $\left(\varepsilon \mathrm{Nd}_{\mathrm{T}} \approx-7.2\right.$; Tilton et al. 1989) correspond to a $\mathrm{T}_{\mathrm{DM}}$ model age of 1,250-1,400 Ma for the crustal protolith and fall in the range typically encountered in mixed-source Paleozoic magmatic and sedimentary rocks of Central 
Europe (see compilation in Romer and Hahne 2010). For Paleozoic rocks, ${ }^{87} \mathrm{Sr} /{ }^{86} \mathrm{Sr}$ ratios as high as $0.745 \pm 0.005$ (Tilton et al. 1989) are typically found in highly fractionated granitoids (i.e., high ${ }^{87} \mathrm{Rb} /{ }^{86} \mathrm{Sr}$ because of high $\mathrm{Rb}$ contents) or profoundly weathered sediments (high ${ }^{87} \mathrm{Rb} /{ }^{86} \mathrm{Sr}$ because of low $\mathrm{Sr}$ contents; for examples see Romer et al. 2012). The $\mathrm{Pb}$ isotopic compositions fall above the $\mathrm{Pb}$ evolution curve for average crust and reflect a pre-metamorphic average $\mathrm{Th} / \mathrm{U}_{\text {atomic }}$ ratio of c. 6.3 (cf. Tilton et al. 1989). Such high $\mathrm{Th} / \mathrm{U}_{\text {atomic }}$ ratios are typically found in high-grade metamorphic rocks and chemically deeply weathered sediments, as these rocks experienced loss of $\mathrm{U}$ and $\mathrm{Pb}$ relative to Th (e.g., Zartman and Haines 1988; Romer and Hahne 2010). Oxygen and hydrogen isotope data from the whiteschists of Dora-Maira are unusual as these rocks are characterized by light $\delta^{18} \mathrm{O}$ and heavy $\delta \mathrm{D}$ values (Sharp et al. 1993). The stable isotope data were interpreted to reflect metasomatism of an igneous protolith (orthogneiss) by a slab-derived fluid (Sharp et al. 1993). These $\delta^{18} \mathrm{O}$ and $\delta \mathrm{D}$ data, however, permit also an alternative interpretation, as they fall between the kaolinite and meteoric water lines (Fig. 13 in Sheppard and Gilg 1996) and overlap with the compositional range of hydrothermal clay minerals (Sheppard and Gilg 1996). Redeposition of terrigeneous kaoline to a marine environment and subsequent heating and re-equilibration would also move $\delta^{18} \mathrm{O}$ and $\delta \mathrm{D}$ into the field between the kaolinite and the meteoric water lines (Fig. 12 in Sheppard and Gilg 1996). Combining the $\mathrm{Sr}-\mathrm{Nd}-\mathrm{Pb}$ isotope systematics with $\delta{ }^{18} \mathrm{O}-\delta \mathrm{D}$ of the Dora-Maira whiteschist indicates provenance from old continental crust that has been affected by ancient chemical weathering.

For sedimentary protoliths, the non-traditional stable isotope systems of $\mathrm{Li}$ and $\mathrm{B}$ might be especially helpful to distinguish marine from terrigeneous settings, as $\delta^{7} \mathrm{Li}$ and $\delta^{11} \mathrm{~B}$ values of seawater $(+31.5$ and $+39.5 \%$, respectively) are much higher than corresponding values for magmatic, metamorphic, and sedimentary rocks and for river and lake waters (e.g., Rose et al. 2000; Tomascak 2004). Sediments deposited in a marine evaporitic environment should have higher $\delta^{7} \mathrm{Li}$ and $\delta^{11} \mathrm{~B}$ values than sediments deposited in a continental evaporitic basin. It is, however, unclear to which extent the original $\delta^{7} \mathrm{Li}$ and $\delta^{11} \mathrm{~B}$ of the sediments are preserved in the metamorphic rocks. Experimental data demonstrate that the fluid generally has a higher $\delta^{7} \mathrm{Li}$ and $\delta^{11} \mathrm{~B}$ value than the co-existing mineral (e.g., Wunder et al. 2005, 2007; Meyer et al. 2008), and there is a tendency to lose $\mathrm{Li}$ and $\mathrm{B}$ with progressive metamorphism (e.g., Leemann and Sisson 1996; Zack et al. 2003). Thus, metamorphic rocks are expected to have lower $\delta^{7} \mathrm{Li}$ and $\delta^{11} \mathrm{~B}$ values than their protoliths, an expectation that is apparently supported by the occurrence of high-grade metamorphic rocks with particularly low $\delta^{7} \mathrm{Li}$ and $\delta^{11} \mathrm{~B}$ (e.g., Zack et al. 2003). The loss-history of $\mathrm{Li}$ and $\mathrm{B}$ during progressive metamorphism, however, is not only controlled by fluid loss, but also by the stability of minerals that sequester significant amounts of $\mathrm{Li}$ and $\mathrm{B}$ and, thus, reduce both the mobility and isotopic fractionation of $\mathrm{Li}$ and $\mathrm{B}$ during metamorphism. As metamorphism tends to decrease $\delta^{7} \mathrm{Li}$ and $\delta^{11} \mathrm{~B}$ in the rock, whiteschists with high $\delta^{7} \mathrm{Li}$ and $\delta^{11} \mathrm{~B}$ values likely have been deposited in a marine evaporitic environment.

Finally, as particularly palygorskite- and sepiolite-rich argillaceous sedimentary rocks may develop the whiteschist mineral assemblage (see Figs. 2, 3, 4, S4-S7) and the formation of such rocks strongly depends on palaeoclimate and palaeolatitude (e.g., Callen 1984; Jones and Conko 2011), whiteschist occurrences derived from sedimentary protoliths provide strong constraints on the depositional environment and paleogeographic setting of the protoliths and, thus, indirectly on tectonic models describing the path from sediment to whiteschist.

Acknowledgments We owe thanks to Andreas Wetzel (Basel) for fruitful discussion and scientific support on sedimentological aspects. We thank Knut Hahne (Potsdam) for unpublished major element composition of sample BEHR-97-100 and Jens Krüger (Potsdam) for help with literature search for high $\mathrm{Mg}$, low $\mathrm{Fe}-\mathrm{Ca}$ lithologies. We acknowledge gratefully the inspiring reviews of Chiara Groppo and Jörg Hermann as well as the editing work of Timothy Grove.

\section{References}

Allen RL, Weihed P, Svensson S-A (1996) Setting of $\mathrm{Zn}-\mathrm{Cu}-\mathrm{Au}-\mathrm{Ag}$ massive sulfide deposits in the evolution and facies architecture of a $1.9 \mathrm{Ga}$ marine volcanic arc, Skellefte District, Sweden. Econ Geol 91:1022-1053

Aranovich LY, Newton RC (1999) Experimental determination of $\mathrm{CO}_{2}-\mathrm{H}_{2} \mathrm{O}$ activity-composition relations at 600-1000 degrees $\mathrm{C}$ and 6-14 kbar by reversed decarbonation and dehydration reactions. Am Mineral 84:1319-1332

Barnes JD, Selverstone J, Sharp ZD (2004) Interaction between serpentinite devolatilization, metasomatism and strike-slip strain localization during deep-crustal shearing in the Eastern Alps. J Metam Geol 22:283-300

Berman RG (1991) Thermobarometry using multiequilibrium calculations: a new technique with petrologic applications. Can Mineral 29:833-855

Bish DL, Guthrie GD Jr (1993) Mineralogy of clay and zeolite dusts (exclusive of 1:1 layer silicates). In: Guthrie GD Jr, Mossman BT (eds) Health effects of mineral dusts, Rev in Mineral, vol 28. Mineralogical Society of America, Washington, DC, pp 139-184

Bonatti E, Joensuu O (1968) Palygorskite from Atlantic deep sea sediments. Am Mineral 53:975-983

Brogi A, Giorgetti G (2012) Tectono-metamorphic evolution of the siliciclastic units in the Middle Tuscan Range (inner Northern Apennines) Mg-carpholite bearing quartz veins related to synmetamorphic syn-orogenic foliation. Tectonophysics 526-529: 167-184

Brueckner HK (2006) Dunk, dunkless and re-dunk tectonics: a model for metamorphism, lack of metamorphism, and repeated metamorphism in HP/UHP terranes. Int Geol Rev 48:978-995 
Callen RA (1984) Clays of the palygorskite-sepiolite group: depositional environment, age and distribution. Dev Sediment 37:1-37

Chopin C (2003) Ultrahigh-pressure metamorphism: tracing continental crust into the mantle. Earth Planet Sci Lett 212:1-14

Chopin C, Monié P (1984) A unique magnesiochloritoid-bearing, high pressure assemblage from the Monte Rosa, W. Alps: a petrologic and ${ }^{40} \mathrm{Ar}^{39} \mathrm{Ar}$ radiometric study. Contrib Mineral Petrol 87:388-398

Chopin C, Schreyer W (1983) Magnesiocarpholite and magnesiochloritoid: two index minerals of pelitic blueschists and their preliminary phase relations in the model system $\mathrm{MgO}-\mathrm{Al}_{2} \mathrm{O}_{3}-$ $\mathrm{SiO}_{2}-\mathrm{H}_{2} \mathrm{O}$. Am J Sci 283A:72-96

Chopin C, Henry C, Michard A (1991) Geology and petrology of the coesite-bearing terrain, Dora Maira massif, Western Alps. Eur J Mineral 3:263-291

Christ CL, Hathaway JC, Hostetler PB, Shepard AO (1969) Palygorskite: new X-ray data. Am Mineral 54:198-205

Church TM, Velde B (1979) Geochemistry and origin of a deep-sea pacific palygorskite deposit. Chem Geol 25:31-39

Compagnoni R, Hirajima T (2001) Superzoned garnets in the coesitebearing Brossasco-Isasca Unit, Dora-Maira massif, Western Alps, and the origin of the whiteschists. Lithos 57:219-236

Couture RA (1977) Composition and origin of palygorskite-rich and montmorillonite-rich zeolite-containing sediments from the Pacific Ocean. Chem Geol 19:113-130

Dal Piaz GV (1988) Revised setting of the Piedmont zone in the northern Aosta valley, western Alps. Ofioliti 13:157-162

Dal Piaz GV, Ernst WG (1978) Areal geology and petrology of eclogites and associated metabasites from the Piemonte ophiolite nappe, Breuil-St. Jacques area, Italian western Alps. Tectonophysics 51:99-126

De Capitani C (1994) Gleichgewichts-Phasendiagramme: Theorie und Software. Beih Eur J Mineral 6:48

De Capitani C, Brown TH (1987) The computation of chemical equilibrium in complex systems containing non-ideal solutions. Geochim Cosmochim Acta 51:2639-2652

De Capitani C, Petrakakis K (2010) The computation of equilibrium assemblage diagrams with Theriak/Domino software. Am Mineral 95:1006-1016

de Pablo-Galán L (1996) Palygorskite in Eocene-Oligocene lagoonal environment, Yucatán, Mexico. Revista Mexicana de Ciencias Geológicas 13:94-103

Dhannoun HY, Al-Dabbagh SMA (1988) Origin and chemistry of palygorskite-bearing rocks (Middle Eocene) from Northeast Iraq. Chem Geol 69:95-101

Ernst G (2001) Subduction, ultrahigh-pressure metamorphism, and regurgitation of buoyant crustal slices-implications for arcs and continental growth. Phys Earth Planet Int 127:253-275

Ferrando S (2012) Mg-metasomatism of metagranitoids from the Alps: genesis and possible tectonic scenarios. Terra Nova. doi:10.1111/j.1365-3121.2012.01078.x

Ferrando S, Frezzotti ML, Petrelli M, Compagnoni R (2009) Metasomatism of continental crust during subduction: the UHP whiteschists from the Southern Dora-Maira Massif (Italian Western Alps). J Metam Geol 27:739-756

Fockenberg T, Schreyer W (1991) Yoderite, a mineral with essential ferric iron: its lack of occurrence in the system $\mathrm{MgO}-\mathrm{Al}_{2} \mathrm{O}_{3}-$ $\mathrm{SiO}_{2}-\mathrm{H}_{2} \mathrm{O}$. Am Mineral 76:1052-1060

Fockenberg T, Schreyer W (1994) Stability of yoderite in the absence and in the presence of quartz: an experimental study in the system $\mathrm{MgO}-\mathrm{Al}_{2} \mathrm{O}_{3}-\mathrm{Fe}_{2} \mathrm{O}_{3}-\mathrm{SiO}_{2}-\mathrm{H}_{2} \mathrm{O}$. J Petrol 35:1341-1375

Franz L, Romer RL, Klemd R, Schmid R, Oberhänsli R, Wagner T, Dong S (2001) Eclogite-facies quartz veins within metabasites of the Dabie Shan (eastern China) pressure-temperature-timedeformation-path, composition of the fluid phase and fluid flow during exhumation of high-pressure rocks. Contrib Mineral Petrol 141:322-346

Frezzotti ML, Ferrando S, Dallai L, Compagnoni R (2007) Intermediate alkali-alumino-silicate aqueous solutions released by deeply subducted continental crust: fluid evolution in UHP $\mathrm{OH}-$ rich topaz-kyanite quartzites from Donghai (Sulu, China). J Petrol 48:1219-1241

Furbish WJ, Sandow TW (1976) Palygorskite; by direct precipitation from a hydrothermal solution. Clay Miner 11:147-152

Gabudianu Radulescu I, Rubatto D, Gregory C, Compagnoni R (2009) The age of HP metamorphism in the Gran Paradiso Massif, Western Alps: a petrological and geochronological study of "silvery micaschists". Lithos 110:95-108

Galán E, Castillio A (1984) Sepiolite-palygorskite in Spanish Tertiary basins-genetical patterns in continental environments. In: Singer A, Galán E (eds) Devel sediment, vol 37. Elsevier, Amsterdam, pp 876-124

Galán E, Pozo M (2011) Palygorskite and sepiolite deposits in continental environments. Description, genetic patterns and sedimentary settings. In: Galán E, Singer A (eds) Developments in clay science, vol 3. Elsevier, Amsterdam, pp 125-173

García-Romero E, Suárez M (2010) On the chemical composition of sepiolite and palygorskite. Clays Clay Miner 58:1-20

Gibbs AE, Hein JR, Lewis SD, McCulloch DS (1993) Hydrothermal palygorskite and ferromanganese mineralization at a central California margin fracture zone. Marine Geo 115:47-65

Goffé B, Chopin C (1986) High-pressure metamorphism in the Western Alps: zoneography of metapelites, chronology and consequences. Schweiz Mineral Petrog Mitt 66:41-52

Groppo C, Lombardo B, Castelli D, Compagnoni R (2007) Exhumation history of the UHPM Brossasco-Isasca Unit, Dora-Maira Massif, as inferred from a phengite-amphibole eclogite. Int Geol Rev 49:142-168

Guchereau JY (1975) Le Saint Barthélémy métamorphique (Pyrénées ariégeoises), pétrographie et structure: Unpub Spec thesis Univ Toulouse, $\mathrm{p} 155$

Hannington MD, Kjarsgaard IM, Galley AG, Taylor B (2003) Mineral-chemical studies of metamorphosed hydrothermal alteration in the Kristineberg volcanogenic massive sulfide district, Sweden. Mineral Dep 38:423-442

Hermann J (2003) Experimental evidence for diamond-facies metamorphism in the Dora Maira massif. Lithos 70:163-182

Hermann J, Green DH (2001) Experimental constraints on high pressure melting in subducted crust. Earth Plant Sci Lett 188:149-168

Heystek H, Schmidt ER (1953) The mineralogy of the attapulgitemontmorillonite deposit in the Springbok flats, Transvaal. Geol Soc South Africa Trans 56:99-119

Irkec T, Ünlü T (1993) An example to sepiolite formation in volcanic belts by hydrothermal alteration: Kibriscik (Bolu) sepiolite occurrence. Mineral Res Expl Bull 115:49-68

Isphording WC (1973) Discussion of the occurrence and origin of sedimentary palygorskite-sepiolite deposits. Clays Clay Miner 21:591-601

Isphording WC (1984) The clays from Yukatán, Mexico: a contrast in genesis. In: Singer A, Galán E (eds) Dev Sediment, vol 37. Elsevier, Amsterdam, pp 75-86

John T, Schenk V, Mezger K, Tembo F (2004) Timing and P-T evolution of whiteschist metamorphism in the Lufilian ArcZambesi Belt orogen (Zambia) implications for the assembly of Gondwana. J Geol 112:71-90

Johnson SP, Oliver GJH (2002) High $\mathrm{fO}_{2}$ metasomatism during whiteschist metamorphism, Zambezi Belt, Northern Zimbabwe. J Petrol 43:271-290

Johnson SP, de Waele B, Tembo F, Katongo C, Tani K, Chang Q, Iizuka T, Dunkley D (2007) Geochemistry, geochronology and 
isotopic evolution of the Chewore-Rufunsa Terrane, Southern Irumide Belt: a Mesoproterozoic continental margin arc. J Petrol 48:1411-1441

Jones BF (1986) Clay mineral diagenesis in lacustrine sediments. US Geol Surv Bull 1578:291-300

Jones BF, Conko M (2011) Environmental influence on the occurrence of sepiolite and palygorskite: a brief review. In: Galán E, Singer A (eds) Developments in clay science, vol 3. Elsevier, Amsterdam, pp 69-83

Jöns N, Schenk V (2004) Petrology of whiteschists and associated rocks at Mautia Hill (Tanzania) Fluid infiltration during highgrade metamorphism? J Petrol 45:1959-1981

Karl SM, Wandless GA, Karpoff AM (1992) Sedimentological and geochemical characteristics of LEG 129 siliceous deposits In: Larson RL, Lancelot Y (eds) Proceedings of the ocean drilling program, scientific results, vol 129. Ocean Drilling Program, Texas A \& M University, College Station, TX, pp 31-79

Karpoff AM (1992) Cenozoic and Mesozoic sediments from the Pigafetta Basin, LEG 129, sites 800 and 801: mineralogical and geochemical trends of the deposits overlying the oldest oceanic crust. In: Larson RL, Lancelot Y (eds) Proceedings of the ocean drilling program, scientific results, vol 129. Ocean Drilling Program, Texas A \& M University, College Station, TX, pp 3-30

Kretz R (1983) Symbols for rock-forming minerals. Am Mineral 68:277-279

Kulke HG, Schreyer W (1973) Kyanite-talc schist from Sar e Sang, Afghanistan. Earth Planet Sci Lett 1B:324-328

Le Bayon R, De Capitani C, Chopin C, Frey M (2006) Modeling phase-assemblage diagrams for magnesian metapelites in the system $\mathrm{K}_{2} \mathrm{O}-\mathrm{FeO}-\mathrm{MgO}-\mathrm{Al}_{2} \mathrm{O}_{3}-\mathrm{SiO}_{2}-\mathrm{H}_{2} \mathrm{O}$ : geodynamic consequences for the Monte Rosa nappe, Western Alps. Contrib Mineral Petrol 151:395-412

Leemann WP, Sisson VB (1996) Geochemistry of boron and its implications for crustal and mantle processes. In: Grew ES, Anovitz LM (eds) Boron-mineralogy, petrology and geochemistry, Rev in Mineral, vol 33. Mineralogical Society of America, Washington, DC, pp 645-707

Lowenstein TK, Timofeef MN, Brennan ST, Hardie LA, Demicco RV (2001) Oscillations in Phanerozoic seawater chemistry: evidence from fluid inclusions. Science 294:1086-1088

McKie D (1959) Yoderite, a new hydrous magnesium iron aluminosilicate from Mautia Hill. Mineral Mag 32:282-307

Meffan-Main S, Cliff RA, Barnicoat AC, Lombardo B, Compagnoni R (2004) A Tertiary age for Alpine high-pressure metamorphism in the Gran Paradiso massif, Western Alps: a Rb-Sr microsampling study. J Metam Geol 22:267-281

Meyer C, Wunder B, Meixner A, Romer RL, Heinrich W (2008) Boronisotope partitioning between tourmaline and fluid: an experimental re-investigation. Contrib Mineral Petrol 156:259-267

Moine B, Sauvan P, Jarousse J (1981) Geochemistry of evaporitebearing series: a tentative guide for the identification of metaevaporites. Contrib Mineral Petrol 76:401-412

Moine B, Fortune JP, Moreau P, Viguier F (1989) Comparative mineralogy, geochemistry, and conditions of formation of two metasomatic talc and chlorite deposits: Trimouns (Pyrenees, France) and Rabenwald (Eastern Alps, Austria). Econ Geol 84:1398-1416

Moreau P (1981) Le massif de Rabenwald (Autriche) et ses mineralizations (talc, chlorite, disthène, leucophyllite) Unpub Spec thesis Besançon Univ, p 397

Munz IA (1990) Whiteschists and orthoamphibole-cordierite rocks and the P-T-t path of the Modum Complex, South Norway. Lithos 24:181-200

Murray HM, Pozo M, Galán E (2011) An introduction to palygorskite and sepiolite deposits-location, geology and uses. In: Galán E, Singer A (eds) Developments in clay science, vol 3. Elsevier, Amsterdam, pp 85-105
Okrusch M, Richter P, Guerkan A (1981) Geochemistry of Blackwall sequences in the Habachtal emerald deposit, Hohe Tauern, Austria, part I: presentation of geochemical data. Tschermaks Mineral Petrog Mitt 29:9-31

Pawling S, Baumgartner LP (2001) Geochemistry of a talc-kyanitechloritoid shear zone within the Monte Rosa granite, Val d'Ayas, Italy. Schweiz Mineral Petrog Mitt 81:329-346

Plank T, Langmuir CH (1998) The chemical composition of subducting sediment and its consequences for the crust and mantle. Chem Geol 145:325-394

Post JL (1978) Sepiolite deposits of the Las Vegas, Nevada area. Clays Clay Miner 26:58-64

Radic A, Lacan F, Murray JW (2011) Iron isotopes in the seawater of the equatorial Pacific Ocean: new constraints for the oceanic iron cycle. Earth Planet Sci Lett 306:1-10

Reinecke T (1991) Very-high-pressure metamorphism and uplift of coesite-bearing metasediments from the Zermatt-Saas zone, Western Alps. Eur J Mineral 3:7-17

Reinecke T (1998) Prograde high- to ultrahigh-pressure metamorphism and exhumation of oceanic sediments at Lago di Cignana, Zermatt-Saas Zone, western Alps. Lithos 42:147-189

Richards HG, Cann JR, Jensenius J (1989) Mineralogical zonation and metasomatism of the alteration pipes of Cyprus sulfide deposits. Econ Geol 84:91-115

Rimmelé G, Oberhänsli R, Goffé B, Jolivet L, Candand O, Cetinkaplan M (2003) First evidence of high-pressure metamorphism in the "Cover Series" of the southern Menderes Massif. Tectonic and metamorphic implications for the evolution of SW Turkey. Lithos 71:19-46

Rogers LG, Martin AG, Norrish K (1954) Palygorskite from Queensland. Mineral Mag 30:534-540

Rolfo F, Compagnoni R, Xu S, Jiang L (2000) First report of felsic whiteschist in the ultrahigh-pressure metamorphic belt of Dabie Shan, China. Eur J Mineral 12:883-898

Romer RL, Hahne K (2010) Life of the Rheic Ocean: scrolling through the shale record. Gond Res 17:236-253

Romer RL, Förster H-J, Hahne K (2012) Strontium isotopes-a persistent tracer for the recycling of Gondwana crust in the Variscan Orogen. Gond Res 22:262-278

Rose EF, Chaussidon M, France-Lanord C (2000) Fractionation of Boron isotopes during erosion processes: the example of Himalayan rivers. Geochim Cosmochim Acta 64:397-408

Roselle GT, Engi M (2002) Ultra high pressure (UHP) terrains: lessons from thermal modeling. Am J Sci 302:410-441

Sánchez C, Galán E (1995) An approach to the genesis of palygorskite in a Neogene-Quaternary continental basin using principal factor analysis. Clay Miner 30:225-238

Schandl ES, O`Hanley DS, Wicks FJ (1989) Rodingites in serpentinized ultramafic rocks of the Abitibi greenstone belt, Ontario. Can Mineral 27:579-591

Schreyer W (1973) Whiteschist: a high-pressure rock and its geologic significance. J Geol 81:735-739

Schreyer W (1974) Whiteschist, a new type of metamorphic rock formed at high pressures. Geol Rundsch 63:597-609

Schreyer W (1977) Whiteschists: their compositions and pressuretemperature regimes based on experimental, field, and petrographic evidence. Tectonophysics 43:127-144

Schreyer W (1988) Experimental studies on metamorphism of crustal rocks under mantle pressures. Mineral Mag 52:1-26

Sharp ZD, Barnes JD (2004) Water-soluble chlorides in massive seafloor serpentinites: a source of chloride in subduction zones. Earth Planet Sci Lett 226:243-254

Sharp ZD, Essene EJ, Hunziker JC (1993) Stable isotope geochemistry and phase equilibria of coesite-bearing whiteschists, Dora Maira Massif, western Alps. Contrib Mineral Petrol 114: $1-12$ 
Sheppard SMF, Gilg HA (1996) Stable isotope geochemistry of clay minerals. Clay Miner 31:1-24

Shmulovich KI, Graham CM (2004) An experimental study of phase equilibria in the systems $\mathrm{H}_{2} \mathrm{O}-\mathrm{CO}_{2}-\mathrm{CaCl}_{2}$ and $\mathrm{H}_{2} \mathrm{O}-\mathrm{CO}_{2}-\mathrm{NaCl}$ at high pressures and temperatures $\left(500-800^{\circ} \mathrm{C}, 0.5-0.9 \mathrm{GPa}\right)$ geological and geophysical applications. Contrib Mineral Petrol 146:450-462

Singer A (1979) Palygorskite in sediments: detrital, diagenetic or neoformed-a critical review. Geol Rundsch 68:996-1008

Singer A (1980) The palaeoclimatic interpretation of clay minerals in soils and weathering profiles. Earth Sci Rev 15:303-326

Singer A (1984) Pedogenic palygorskite in arid environment. In: Singer A, Galán E (eds) Developments in sedimentology, vol 37. Elsevier, Amsterdam, pp 169-177

Spear FS (1993) Metamorphic phase equilibria and pressuretemperature-time paths. Mineral Soc Am Monograph, p 700

Stephen I (1954) An occurrence of palygorskite in the Shetland isles. Mineral Mag 30:471-480

Tilton GR, Schreyer W, Schertl H-P (1989) Pb-Sr-Nd isotopic behavior of deeply subducted crustal rocks from the Dora Maira Massif, Western Alps, Italy. Geochim Cosmochim Acta 53:1391-1400

Tomascak PB (2004) Development in the understanding and application of lithium isotopes in the Earth and planetary sciences. In: Johnson CC, Beard BL, Albarède F (eds) Geochemistry of nontraditional stable isotopes, Rev in Mineral, vol 55. Mineralogical Society of America, Washington, DC, pp 153-195

Torres-Ruiz' J, López-Galindo A, González-López JM, Delgado A (1994) Geochemistry of Spanish sepiolite-palygorskite deposits: genetic considerations based on trace elements and isotopes. Chem Geol 112:221-245

Van der Klauw SNGC, Reinecke T, Stöckert B (1997) Exhumation of ultrahigh-pressure metamorphic oceanic crust from Lago di Cignana, Piemontese zone, western Alps: the structural record in metabasites. Lithos 41:79-102

Vivallo W, Willdén M (1988) Geology and geochemistry of an early Proterozoic volcanic arc sequence at Kristineberg, Skellefte district, Sweden. GFF Geol Fören Stockholm Förhandl 110:1-12

Warren JK (2010) Evaporites through time: tectonic, climatic and eustatic controls in marine and nonmarine deposits. Earth Sci Rev 98:217-268
Wei C, Powell R (2003) Phase relations in high-pressure metapelites in the system KFMASH $\left(\mathrm{K}_{2} \mathrm{O}-\mathrm{FeO}-\mathrm{MgO}-\mathrm{Al}_{2} \mathrm{O}_{3}-\mathrm{SiO}_{2}-\mathrm{H}_{2} \mathrm{O}\right)$ with application to natural rocks. Contrib Mineral Petrol 145:301-315

Wunder B, Meixner A, Romer RL, Wirth R, Heinrich W (2005) The geochemical cycle of boron: constraints from boron isotope partitioning experiments between mica and fluid. Lithos 84:206-216

Wunder B, Meixner A, Romer RL, Feenstra A, Schettler G, Heinrich W (2007) Lithium isotope fractionation between Li-bearing staurolite, Li-mica and aqueous fluids: an experimental study. Chem Geol 238:277-290

Wyllie PJ (1992) Experimental petrology: earth materials science. In: Brown G, Hawkesworth C, Wilson C (eds) Understanding the earth. Cambridge University Press, Cambridge, pp 82-84

Yamato P, Burov E, Agard P, Le Pourhiet L, Jolivet L (2008) HPUHP exhumation during slow continental subduction: selfconsistent thermodynamically and thermomechanically coupled model with application to the Western Alps. Earth Planet Sci Lett 271:63-74

Yeniyol M (1986) Sepiolite replacement of magnesite. Clays Clay Miner 34:353-356

Zack T, Tomascak PB, Rudnick RL, Dalpé C, McDonough WF (2003) Extremely light $\mathrm{Li}$ in orogenic eclogites: the role of isotope fractionation during dehydration in subducted oceanic crust. Earth Planet Sci Lett 208:279-290

Zartman RE, Haines SM (1988) The plumbotectonic model for $\mathrm{Pb}$ isotopic systematics among major terrestrial reservoirs; a case for bi-directional transport. Geochim Cosmochim Acta 52:13271339

Ziegler CL, Murray RW, Plank T, Hemming SR (2008) Sources of Fe to the equatorial Pacific Ocean from the Holocene to Miocene. Earth Planet Sci Lett 270:258-270

Zwart HJ (1953) La géologie du massif du Saint-Barthélémy. Leidse Geol Meded 18:228 